Discussion Paper No. 05-95

Descriptive Evidence on Labor Market Transitions and the Wage Structure in Germany

Bernd Fitzenberger and Alfred Garloff

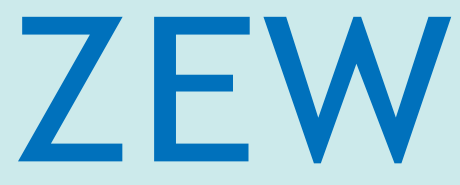

Zentrum für Europäische Wirtschaftsforschung $\mathrm{GmbH}$

Centre for European

Economic Research 
Discussion Paper No. 05-95

\title{
Descriptive Evidence on Labor Market Transitions and the Wage Structure in Germany
}

\author{
Bernd Fitzenberger and Alfred Garloff
}

Download this ZEW Discussion Paper from our ftp server:

ftp://ftp.zew.de/pub/zew-docs/dp/dp0595.pdf

Die Discussion Papers dienen einer möglichst schnellen Verbreitung von neueren Forschungsarbeiten des ZEW. Die Beiträge liegen in alleiniger Verantwortung der Autoren und stellen nicht notwendigerweise die Meinung des ZEW dar.

Discussion Papers are intended to make results of ZEW research promptly available to other economists in order to encourage discussion and suggestions for revisions. The authors are solely responsible for the contents which do not necessarily represent the opinion of the ZEW. 


\section{Nontechnical summary}

This study provides a comprehensive descriptive analysis of labor market transitions and wage mobility in the German labor market based on a large administrative data set, the IAB employment subsample 75-97. The analysis is motivated by equilibrium search theory, which predicts a close relationship between labor market frictions and the wage distribution in a cross section of workers. The friction parameters govern job separations (job destruction rate) and job accessions (job offer rate), thus determining the residual wage dispersion for a set of workers with comparable attributes. The basic argument is the existence of imperfect information ("slow" job accession) on the one hand and economic turbulence (job destruction) on the other hand.

As the first step of our analysis, we provide a detailed analysis of job destructions, job accessions, job-to-job transitions, and all other labor market transitions, which are identifiable in our data set. We focus on the differences across individuals with different characteristics as well as on the cyclical behavior of transition rates. The latter reveals information on cleansing and sullying effects of the business cycle. The time series properties of both stocks and transition rates are considered. The data show marked differences across different groups of individuals. Some of these differences are consistent with search theory and other labor market theories. For example, the data confirm that individuals often change jobs when they are young and when they earn lower wages. It is also found that individuals with low formal educational level are most likely to become benefit recipients and that they are least likely to be employed in two consecutive periods. Regarding cyclical features, we find that the job-to-job transition rate is clearly procyclical, while the rate of transitions from job to benefit recipiency is clearly countercyclical.

Human capital theory predicts a central role for the acquisition of human capital on the job for wage growth, while search theory predicts a central role of job mobility for wage growth during the course of an individual's career. As the second step of our analysis, we examine direct job-to-job transitions and associated wage changes, We control for the position in the wage distribution and other characteristics. We find that most individuals (almost two thirds) gain from job mobility, earning on average about $25 \%$ more after the transition. This is well in accordance with a search-theoretic approach. But, it has to be recognized, that a considerable amount of individuals lose from job-to-job transitions and they lose a considerable amount (15\% on average), which is hardly explicable by a simple search-theoretic model. We also find that low wage earners gain more often from job mobility and that their average gains are higher (as a percentage of their previous earnings). Regarding job mobility involving an 
intervening unemployment spell, we find that a longer unemployment spell is associated with slightly lower chances to improve upon the previous wage, while the average gain of those who improve increases.

Finally, we analyze the determinants of improvements of the relative position in the wage distribution. We consider all individuals employed in two consecutive years and we classify them according to the wage decile in both years. Estimating an Ordered Probit, we analyze the determinants of upward or downward mobility in the wage distribution. We find that job-to-job transitions play a crucial role for wage mobility and that the propensity to move up the wage ladder is higher for younger compared to older individuals. Summarizing, our analysis supports the view that wages and transitions are closely related and that job mobility is a central determinant of wage growth. 


\title{
Descriptive Evidence on Labor Market Transitions and the Wage Structure in Germany
}

\author{
Bernd Fitzenberger (Goethe-University Frankfurt, ZEW, IFS, and IZA) \\ Alfred Garloff (ZEW)*
}

November 2005

\begin{abstract}
Equilibrium search theory suggests that the wage distribution in a cross section of workers is closely related to labor market transitions and associated wage changes. Accordingly, job-to-job transitions are central in explaining the wage distribution. This paper uses the IAB employment subsample to describe the empirics of labor market transitions and the wage structure in Germany. Motivated by search theory, we use the data to explore descriptively labor market transitions and features of the wage structure. We find that labor market transition rates vary substantially over the business cycle and with individual characteristics. Regarding job-to-job transitions, we find considerable wage changes. Most job changes involve considerable gains, but a number of individuals incurs a remarkable loss. Regarding the wage structure, we find strong effects of job-to-job transitions, age, and education on wage mobility. Based on our descriptive analysis, we conclude that indeed a close relationship exists between wages and labor market transitions as predicted by search theory. However, the noticeable share of wage losses following job-to-job changes contradicts a simple search theoretic perspective.
\end{abstract}

Keywords: search friction, labor market transitions, wages

JEL-Classification: E24, J21, J31, J64

\footnotetext{
* This work is part of the research project "Formation and Utilization of Differentiated Human Capital" as a part of the research group "Heterogeneous Labor: Positive and Normative Aspects of the Skill Structure of Labor". Support from the German Science Foundation (DFG) is gratefully acknowledged. We would like to thank Tobias Hagen, Karsten Kohn, and Anja Kuckulenz and Alexander Spermann for helpful comments and Michaela Deppe as well as Jenny Meyer, Iliyan Stankov and Tobias Tönnesmann for helpful research assistance. The usual disclaimer applies.

Correspondence: Bernd Fitzenberger, Faculty of Business and Economics, Goethe-University, PO Box 111932 (PF 247), 60054 Frankfurt am Main, Germany. E-mail: fitzenberger@wiwi.uni-frankfurt.de Alfred Garloff, Zentrum für Europäische Wirtschaftsforschung (ZEW), Postfach 1034 43, D-68034 Mannheim, E-mail: garloff@zew.de
} 


\section{Contents}

\begin{tabular}{lll}
\hline & Introduction & 1
\end{tabular}

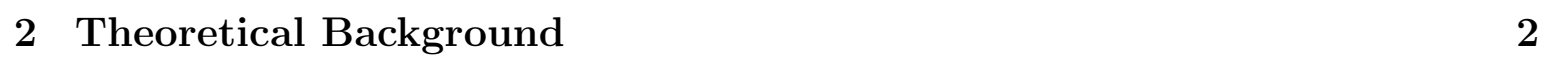

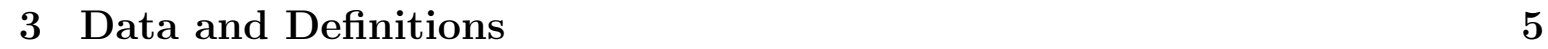

\begin{tabular}{|lll}
4 & Empirical Results & 8
\end{tabular}

4.1 Stocks and Flows . . . . . . . . . . . . . . . . . . . . . . . . . . . 8

4.2 Wage Changes following Job-to-Job Transitions . . . . . . . . . . . . . 15

4.3 Wage Structure and Changes in the Relative Wage Position . . . . . . 20

\begin{tabular}{lll}
\hline 5 & Conclusions & 23
\end{tabular}

\begin{tabular}{ll}
\hline References & 24
\end{tabular}

\begin{tabular}{ll}
\hline A Appendix & 27
\end{tabular}

A.1 Abbreviations . . . . . . . . . . . . . . . . . . . . . . . . . . 27

A.2 Average stocks and transitions rates across demographic groups . . . . 28

A.3 Development of stocks over time . . . . . . . . . . . . . . . . . . 35

A.4 Wage distributions for different groups and years . . . . . . . . . . . 38

A.5 Results from direct job-to-job changes for different wage definitions . . 39

A.6 Decile Transitions . . . . . . . . . . . . . . . . . . . . . . . . . . . . . . 47 


\section{Introduction}

For a long time the literature in economics has concentrated on a static perspective of the labor market. Since Stigler's seminal paper (1961) on the effect of imperfect information in markets, a huge literature on price dispersion for identical products and the decision problems for either side of the market has developed. By nature, the process of acquiring information is time-consuming and therefore dynamic. We conduct an empirical analysis on labor market dynamics and wages based on this theoretical background, which is now seen as "the canonical framework for the analysis of labor markets" (Moscarini (2003)). This paper intends to give a comprehensive empirical overview on wages and employment dynamics in the labor market without a priori restrictions on the data. We investigate differences in transition rates and in the wage structure over time and across individuals with specific characteristics. Our results cannot be used to discriminate between competing theories of the labor market in a strict sense. Nevertheless, in a number of cases the results allow to assess whether theoretical predictions are consistent with the data.

The motivation for this paper and, especially, for considering labor market transitions and wages together builds on equilibrium search theory (see Mortensen (2003) for an overview). In their seminal work on equilibrium wage dispersion for homogeneous workers Burdett and Mortensen (1998) show that the amount of frictions determines the extent of wage dispersion for homogeneous workers in a labor market. Frictions themselves can be measured by labor market transitions. To see this, recognize that frictions persist because there is imperfect information in the labor market. Individuals do not know their outside wages and have to acquire this information in a time-consuming process. Once they have acquired the information, they process it and take the optimal decision based on a standard optimization problem. This implies, for instance, that individuals climb the wage ladder slowly, and that wage differentials diminish over time. Since jobs do not last forever, but also end for reasons beyond the control of firms and workers, the process does not converge to a single wage, and an equilibrium cross-sectional wage distribution exists 11 This argument identifies two important friction parameters in search theory: the job offer rate and the job destruction rate. The first can be viewed as reflecting informational frictions, being the result of the process of acquiring information. The second parameter represents the amount of turbulence and shocks in the economy (see e.g. Mortensen and Pissarides (1994)). Because of the importance of frictions for the wage distribution, we scrutinize the changes in these friction parameters over time and across demographic groups.

Human capital theory assumes that the wage growth of individuals over time is mainly caused by the acquisition of human capital while working in a given job. Search theory suggests that the main source of wage growth over the course of an individual's career

\footnotetext{
${ }^{1}$ Note, that the above argument also implies that the distribution of wages in a cross section of workers is not the same as the distribution of wages in a cross section of newly created jobs.
} 
is the wage growth caused by (voluntary) job-to-job transitions. This leads us to examine the wage growth associated with job-to-job transitions. Since it might be the wage-tenure profile instead of the level of wages which influences the decision to change the job, we also investigate the wage growth of job movers and stayers (see e.g. Postel-Vinay and Robin (2002b), Burdett and Coles (2003) and Stevens (2004)). Finally, we take a closer look at the determinants of changing the relative position in the wage distribution to analyze the factors determining the relative success in the labor market and the importance of job-to-job transitions in this respect.

The outline of the paper is as follows. Section 2 states the results of search theory, that motivate our analysis. Section 3 describes the data set used. In section 4, we state some facts about stocks and rates, their differences across groups, and their cyclical behavior. Afterwards, we investigate in some detail the job-to-job transitions and their impact on wages for different groups. Finally, we estimate determinants of changes in the relative position of the wage distribution. The last section concludes.

\section{Theoretical Background}

Stigler's (1961) seminal contribution to the literature started a lively debate on the effects of informational imperfections. The literature on informational frictions concentrated first on the search problem of individuals when confronted with different prices for a homogeneous product. It was shown that under certain circumstances the search problem can be interpreted as an optimal stopping problem, where the solution is characterized by a reservation wage/price. The other side of the market was rarely analyzed in detail, i.e. it remained unclear why price/wage dispersion arises. The matching literature (see e.g. Pissarides (2000), who is a major proponent of this literature) suffers strongly from this shortcoming. On the one hand, the motivation for the existence of an informational imperfection is argued to come from heterogenous prices for homogeneous products. On the other hand, in this literature, there is generally just one price in equilibrium, so that it is difficult to argue why informational imperfections exist. Therefore, we shift our focus from the matching literature to the equilibrium search literature.

Stigler's contribution already shows that the amount of information imperfection is somehow related to the degree of price dispersion for a homogeneous product in the market. Burdett and Mortensen (1998) formalize the idea in the context of labor markets. They resolve the Diamond-Paradoxon (1971), which states that under a Poisson-assumption for job offers and wage setting by firms, a non-degenerate price dispersion for homogeneous workers cannot be an equilibrium. ${ }^{2}$ Under Diamond's assumptions, firms have the whole bargaining power over the rent resulting from the

\footnotetext{
${ }^{2}$ A theoretical paper by Albrecht and Axell (1984) that implies an equilibrium wage distribution with two mass points was an earlier attempt to resolve this paradox.
} 
market imperfection. Therefore, identical workers with identical reservation wages are offered the same wage by firms, their reservation wage. The crucial difference in the paper by Burdett and Mortensen (1998) is that workers are allowed to search onthe-job for a better-paying job. This guarantees that the Burdett and Judd (1983) condition for equilibrium price dispersion is met, i.e. that one part of the individuals (here: the employed) is able to compare wages. This yields a trade-off in firms' wage policy, since a higher wage attracts more workers and causes the firms to lose fewer workers to competitors. This essential point of the model guarantees the existence of a non-degenerate equilibrium wage distribution among identical individuals and firms. In equilibrium, high-wage firms have high employment, and make small profits per employee, whereas low-wage firms have low employment and make high profits per employee.

The amount of wage dispersion we observe in this model is directly linked to the possibility of individuals changing jobs. The more often they change jobs, the faster they climb the wage ladder towards their marginal productivity. Hence, the market imperfection is weaker and the wage dispersion is smaller. If jobs never ended, except through job-to-job transitions, unemployment would converge to zero and the wage dispersion to the marginal productivity of the individuals. So, the second determinant (and a necessary condition) for wage dispersion is the frequency at which jobs end for reasons not related to the individuals decision to change a job (called ,,job destruction"). If they end more often, equilibrium unemployment and therefore the inflows into low-wage firms will rise. Accordingly, the frequency of exogenous job destruction acts to increase wage dispersion 3 More formally: consider the model as outlined by Burdett and Mortensen (1998). Let $\lambda_{L}$ denote the rate at which employees receive offers from competing firms (job offer rate). Further, let $\delta$ denote the rate at which jobs end for exogenous reasons. $y$ denotes the marginal productivity and $w_{R}$ the reservation wage of the individuals. Then the resulting equilibrium wage offer distribution is 4

$$
H(w)=\left\{\begin{array}{cl}
0 & \text { for } w<w_{R} \\
\frac{\lambda_{L}+\delta}{\lambda_{L}}\left(1-\sqrt{\frac{y-w}{y-w_{R}}}\right) & \text { for } w_{R} \leq w<w^{o} \\
1 & \text { for } w \geq w^{o}
\end{array}\right.
$$

Hence, the wage distribution is determined by the two frictional parameters $\lambda_{L}$ and $\delta$, the marginal productivity and the reservation wage. However, what is observed in the data is not the wage offer distribution but the distribution of paid wages. The distribution of paid wages is determined by the same parameters, and the link between the two distributions can be derived, assuming equilibrium, as (see Garloff (2003))

(2) $\quad G(w)=\frac{\delta H(w)}{\left(\lambda_{L}(1-H(w))+\delta\right)}$.

\footnotetext{
${ }^{3}$ Both statements are only correct under some parameter restrictions. For a more precise treatment, see Fitzenberger and Garloff (2005).

${ }^{4} \mathrm{~A}$ derivation of this formula can be found in Garloff (2003).
} 
For this distribution we can directly calculate the variance as a wage dispersion measure. It is given by (see Van den Berg and Ridder (1993), p.48ff.)

$$
\operatorname{var}_{G}(w)=1 / 3\left(y-w_{m i n}\right)^{2} \eta(1-\eta)^{2}
$$

where $\eta=\frac{\delta}{\delta+\lambda_{L}}$ is a frictions indicator often used in the search literature, and $w_{\text {min }}$ is a minimum wage. This shows more formally our motivation to deal with labor market dynamics and therefore with the transition rates when thinking about wages. The above formulas show that informational frictions are an important determinant of wages.

There are two major objections against this model. First, the resulting wage distribution is skewed to the left. This is at odds with observed wage distributions which are typically skewed to the right. Even after a segmentation of the labor market in (more or less) homogeneous segments, e.g. in age-education cells as in Fitzenberger and Garloff (2005), or in age-education-profession-industry cells as in Van den Berg and Ridder (1998), (German) wages are not skewed to the left $5^{5}$ Second, a more important drawback is that the model is built for homogeneous individuals and firms. It is difficult to argue that, even after a market segmentation, individuals are homogeneous or at least not distinguishable from the point of view of the firm (see e.g. Abowd, Kramarz, and Margolis (1999), who find a strong individual component in the determinants of wages).

In reaction to these objections, several extensions have been discussed including exogenous or endogenous heterogeneity on the side of the firms (see e.g. Bontemps, Robin, and Van den Berg (2000), Acemoglu and Shimer (2000)), exogenous or endogenous heterogeneity on the side of the workers (see e.g. Burdett and Mortensen (1998), Moen (1999)) or exogenous heterogeneity on both sides of the market (see e.g. Postel-Vinay and Robin (2002b), Teulings and Gautier (2004)). However, all these models have in common that wages are determined partly by search frictions. So the principal insight remains: there is a close connection between labor market dynamics and the wage distribution along the arguments of search theory, which we will assess in more detail later.

Let us summarize our theoretical section by stating empirical implications of search theory.

- There is a close connection between wages and labor market frictions. Labor market frictions in the sense of this paper are informational imperfections and, basically, constitute barriers to mobility. They cause economically motivated labor market transitions not to take place immediately. Labor market transition rates can be seen as an indicator of labor market frictions.

\footnotetext{
${ }^{5}$ On the contrary, Gautier and Teulings (2003) conclude in their application for six OECD countries, including Germany, that the theoretical prediction of a left skewed wage distribution is in accordance with the data.
} 
- Transitions between unemployment and employment depend on the job offer rate when unemployed, job-to-job transitions depend on the job offer rate when employed. Both rates depend both on macroeconomic conditions (e.g. labor market tightness) and on individual behavior (e.g. search intensity).

- Transitions from employment to unemployment depend on the exogenous job destruction rate and therefore on the business cycle.

- The job-to-job transition rate depends on the wage earned in the current job since the probability that an i.i.d. offer from the wage offer distribution exceeds the earned wage declines with wage. By the same argument, the job-to-job transition rate also depends on age, since individuals climb the wage ladder as time progresses.$^{6}$

- Generally speaking, the simple equilibrium search model does not make any predictions how the different rates vary with education, sex, nationality, marital status, professional status or sector. However, in the context of this theoretical framework, we can give most differences a meaningful interpretation.

- Job-to-job transitions are the crucial determinant of wage growth in an individual's career. From the point of view of the simple equilibrium search model presented above, they occur exclusively because of wage gains.

- Average wage gains through job-to-job transitions decrease with the earned wage and with age, since older individuals earn more on average.

- The share of job-to-job transitions involving wage gains decreases with age, since the number of job-to-job transitions that are economically motivated in the sense discussed above decreases, holding other noneconomic reasons that cause job-tojob transitions constant.

\section{$3 \quad$ Data and Definitions}

The empirical analysis is based on the IAB employment subsample (IABS), a large administrative data set for Germany for the time period 1975 to 1997, see Bender, Haas, and Kloose (2000). The IABS contains information from two sources. The first source is the employment statistic based on the integrated notification procedure for health insurance, social security, and unemployment insurance. This way, employers are required to report employment under the social security system which covers about $80 \%$ of all employees. Civil servants, self-employed, helping family, students, and employees earning less than a certain low threshold income are not covered by the system. The second source for the IABS are the transfer payments to the unemployed.

\footnotetext{
${ }^{6}$ This is true only if $\lambda_{L}>\delta$. In our data set this condition is met (see table 3 in the appendix).
} 
The two sources are merged together for a one percent random sample of employees from the social security records. Therefore, by construction, the data set is representative regarding employment covered by the social security system but not regarding unemployment. The information on timing (daily!) of being in one labor market state (spells) and on the gross daily wage (rounded to DM) are exact, except for the wage being censored at the upper social security threshold. Typical panel data problems like panel mortality or commemoration error do not arise. In addition, the data set is big (about 8 millions observations) and (depending on the interpretation) representative for all persons who have been employed at least once in a job that is part of the compulsory notifying procedure in the observed 22 years (more than $80 \%$ of all workers the share is even higher among full-time employed workers). In the data set we can observe three states: employed (E), recipient of transfer payments (i.e. unemployment benefits, unemployment assistance and income maintenance during participation in training programs, BR) and out of sample (OOS) 7 Unfortunately, none of the two last categories corresponds exactly to the economic concept of unemployment. The second state is likely to approximate unemployment better than the third one, since every person being recipient of transfer payments is indeed unemployed from an administrative point of view 8 On the other hand, there are persons who are registered unemployed but who are not entitled to receive transfer payments. During this time, these people are not recorded in the IABS. Thus, they cannot be distinguished from self-employed, civil servants, people being out of labor force and others (see above) who are at least once employed in a recorded job during the time period investigated.

We calculate transition rates between the three states, excluding observations in East Germany and workers with parallel employment spells. These restrictions reduce our sample by about $20 \%$ to 6.6 millions observations. Annual transition rates are based on the labor market state on January 1st of each year 9 Transitions from employment to receiving transfer payments are interpreted as transitions to unemployment 10 since the benefit entitlement period is six months after an employment spell of six months, and it increases to one year after a two year spell 41 In addition, the correlation between

\footnotetext{
${ }^{7}$ In addition, we could distinguish between people being out of sample between two spells of different states and between people who are at one point in time not in the data set, but where there is no spell either before or afterwards (broad definition). As an extreme case, the latter might include persons who are dead, whereas the former does not. For most analyses, we use the narrow definition of the third state, i.e. only out of sample spells where there are spells of different states both before and afterwards. Although then, the state OOS is not representative any more, this narrow definition seems more appropriate for our analysis.

${ }^{8}$ With the exception of participants in a training programme. We basically view them as being unemployed since the goal of the programme is to improve the reemployment chances in the future.

${ }^{9}$ The yearly structure implies that our sample is a stock sample, which itself implies a length-biased sampling problem when estimating transition rates. Both short employment and unemployment spells are underrepresented in the data set.

${ }^{10}$ The largest group of workers not contained in the data set are civil servants who are typically tenured (三 no risk of unemployment).

${ }^{11}$ However, we have to note that at least for the US, it is known that most new jobs end early. Farber (1999) finds that in the US about one third of all new full-time jobs end in the first six months, while about two thirds end within the first two years.
} 
the administrative unemployment rate and the share of benefit recipients in our sample is near one. In contrast, transitions from unemployment into employment are not that easily approximated by transitions from receiving transfer payments to employment. Long-term unemployed, whose benefits are exhausted, might find a job, and there might be people shifting from the state receiving transfer payments to the state out of sample by becoming a civil servant or by becoming self-employed. Therefore, in the empirical section, we use different definitions of unemployment to check for consistency of the results.

As wage information we use daily gross wages given in the data set, which are partly censored at an upper social security threshold. Since the censoring threshold is not precise in the data, we observe wages which are slightly above the social security threshold and a clustering of wage observations below this threshold. In addition, for data reasons, there exists another category (wage 300) in the data which indicates censoring. Where we need the wage information, we censor the wages slightly below the social security threshold and replace the censored value by a conditional expectation from a Tobit regression where we assumed that log-wages in every cross section (after conditioning for demographic characteristics) are normally distributed 12 There is also a lower bound in the wage distribution which stems from the fact that below a certain salary threshold jobs are not subject to social insurance contribution (i.e. the wage distribution is truncated from below). But there are wage notifications that are below this threshold and therefore censored and set to 1 in the data set 13 About $1.5 \%$ of the employment spells and $0.2 \%$ of the benefit recipient spells fall in this category. We replace the censored value for part-time employees and apprentices by a conditional expectation from Tobit regressions ${ }^{14}$ Almost $75 \%$ of these censored spells are apprentices, whom we typically exclude from our analysis of wage mobility. Part-time employment, which accounts for further $7 \%$ of these censored values from below, are also excluded from most analyses concerning wage mobility. For individuals who receive benefits, the wage variable contains their last wage, which we adjust with the inflation rate (三CPI). In more than $5 \%$ of the employment spells and in more than $6 \%$ of the benefit recipient spells, the wages are not available because of data errors (wage 0 ). Where we need wages, we exclude these spells from our analysis. There is a second missing category in the wages which is irrelevant for employees, but which we observe in about $6 \%$ of the benefit recipient spells (wage 999). These are the spells which are extrapolated backwards before the first employment spell of an individual that comes from the compulsory notifying procedure. Again, we exclude these spells when we

\footnotetext{
${ }^{12}$ We censor slightly below the threshold because of the clustering around the threshold and since we suspect that there is no real clustering around the social security threshold (see Fitzenberger and Reize (2002)). In the case of clustering, Tobit estimates based on the rounded official daily threshold yield unsatisfactory results, since the estimator tries to fit a fairly high density slightly below the threshold.

${ }^{13}$ These notifications arise from the fact that there are both wage and working time criteria for a job not to be subject to social insurance contribution.

${ }^{14}$ For other employees we suspect that the low wage notifications are incorrect and therefore we set the censored wage values to missing.
} 
need wage observations. Finally, a last problem with the wage variable consists in a structural break between 1983 and 1984. Before 1984, one-time wage payments and non-monetary benefits were not systematically covered in the wage variable, whereas from 1984 onwards they are. We use a time trend and/or year dummies to control for this institutional change. When using wage dispersion measures, we calculate them from cross sections of individuals on January 1st.

For the wage mobility analyses, we construct three skill groups from the education information: The first category corresponds to persons who have neither a completed vocational training nor a university degree (low-skilled). The second category consists of people who have finished a vocational training but have no university degree (medium-skilled). The third group corresponds to persons who have a university degree or a degree from a technical college (high-skilled). Note that the education information in the IABS is not always consistent across time so that we corrected the education information based on the simple rule that a finished degree cannot be lost.

\section{Empirical Results}

First, we describe the stocks of individuals in different labor market states and transition rates over the business cycle and across different demographic groups that we observe in the labor market. The second subsection deals with job-to-job transitions and wage changes that follow such transitions. Finally, we characterize the wage distribution in more detail and examine determinants of wage mobility.

\subsection{Stocks and Flows}

There exists a large literature on worker and job flows in the labor market 15 The literature mainly focuses on the forces behind and on the regularities of worker and job flows, e.g. their cyclical behavior. In our data set, we are not able to calculate job flows, as we cannot identify establishments, but we are able to identify worker flows. Since we do not observe the population, however, but a $1 \%$ random sample, transition rates are more meaningful than flows, which induces us to concentrate on these. Starting with stock sizes, we observe on average about 218.000 individuals on January 1st each year. About 12.500 of these are benefit recipients and 24.000 are out of sample (see table 1). This corresponds to an average benefit recipiency rate of about $5.7 \%$ and to an average rate of $11 \%$ of individuals being out of sample. So about $83 \%$

\footnotetext{
${ }^{15}$ For a comprehensive overview, see Davis and Haltiwanger (1999). A recent paper by Bachmann (2005) analyzes the cyclical behavior of labor market transition rates in West Germany based on the IABS. His results differ from our results. A major difference lies in the definition of the transition rates. While we investigate transitions on a year-to-year basis (there is at most one transition per year), Bachmann (2005) includes multiple transitions in the calculation of transition rates, i.e. individuals with multiple transitions in a year have a higher implied rate.
} 
of the individuals we observe in each cross section are employed. One should recall that the data are a random sample of employees, see previous section.

Figures 1 and 2 in the appendix show the development of the stocks over time. Figure 1 reveals that total employment increases over time until 1981, then decreases until 1985, again increases until 1992, and finally decreases afterwards. Figure 2 raises doubt whether the number of benefit recipients is always correct in the data set. The low number of benefit recipients for 1975 can be explained by the fact that the data for the first year are incomplete, while the number for 1979 seems to be incredible, both for the number of benefit recipients and for the number of individuals that are out of sample. Besides, we have no clear explanation why the number of individuals being out of sample shows a hump-shaped trend over time. Possibly institutional reasons (such as a prolongation of unemployment claims) are responsible for a higher share of individuals that are registered as benefit recipients at the end of the 90s. The rate of benefit recipients shows a stepwise increase, analogous to the widely discussed ratchet effect for the trend in the unemployment rate (Franz (2003)). Employment growth and the growth rate of the number of persons being out of sample are positively correlated with the real GDP growth (correlation coefficients 0.42 and 0.25 , respectively), whereas the growth rate of benefit recipients is not related to real GDP growth (correlation coefficient of 0.02) $t^{16}$ The rate of benefit recipients in our data set is strongly positively related to the official unemployment rate (correlation coefficient of about 0.9) and strongly negatively correlated with the inflation rate (Phillips curve).

Table 1 in the appendix shows that the service sector (business, household, and societal services) is largest comprising around about $25 \%$ of all employees, followed by the producer durable good sector covering about $20 \%$ of the employees 17 The smallest sector is the agricultural sector (including energy, mining and gardening) with less than $3 \%$ of the employees. The construction sector is the sector which has by far the biggest rate of benefit recipients ${ }^{18}$ while in the social security sector it is particularly low (4.2\%).19 The service sector has the highest rate of persons being out of sample (16.1\%), while basic industry has the smallest rate (5.6\%). Concerning the development of sectors over time, the decline of the construction sector starts in the early 80's, but unification leads to a temporary boom in this sector with increasing employment up to 1995. For agriculture, the development is similar but there is no unification boom.

\footnotetext{
${ }^{16}$ The data for the business cycle are based on Statistisches Bundesamt (2000) and own calculations.

${ }^{17}$ When numbers for benefit recipients and out of sample are split according by sectors (other job characteristics), the numbers refer to the sector (the job information) where individuals were previously employed. Note that almost half of the unemployment spells terminate with a change of sector. In the case of sectors one argument to take the former instead of the future sector is that there are much more individuals where the last spell is an benefit recipient spell than there are individuals, where the first spell is a benefit recipient spell.

${ }^{18}$ The benefit recipiency rate for the construction sector (main construction trade plus upgrading) is about $9.3 \%$. However, one should be careful with the interpretation of this result, since we use due date information on the first January of each year. The high benefit recipiency rate in the construction sector might be a seasonal phenomenon.

${ }^{19}$ The numbers refer to the sector information reported for the last job before unemployment.
} 
As expected from tertiarisation of jobs, employment in the service sector(s) increase(s) over the whole 23 years (see figure 5). Employment in local authorities and the social insurance sector is astonishingly constant over time, employing approximately the same number of individuals in 1997 as in 1976 without much variation during this period (see figure 6).

Regarding family status, we observe that on average about half of the employees in a cross section are married (see table 1). Individuals who are not married have a higher probability of being out of sample (13\% versus $9 \%$ ), while the share of benefit recipients is almost identical. Splitting individuals according to their professional status yields that by far the biggest group are clerks (almost 40\%), whereas the smallest group are foreman (about 2\%). Apprentices account for about 7\% of all employees. The highest benefit recipiency rate is listed by unskilled workers (9.1\%).20 The lowest benefit recipiency rate can be found for foremen $(3.5 \%)$, apprentices $(3.1 \%){ }^{21}$ and part-time workers who work less than half of the normal time (1\%). Foremen also have the lowest rate of persons being out of sample $(4.1 \%)$, whereas almost one third of the part-time working individuals, which work less than half of the normal time, are out of sample.

Regarding education, table 1 indicates for uncorrected education data (see page 8) that by far the largest group (about 60\%) are people that have no university-entrance diploma ("Abitur") but a vocational training degree (category 2, in table 1 in the appendix), while about $27 \%$ have neither of these qualifications (category 1). The remainder are persons with a university-entrance diploma or for whom educational attainment is unknown. About 5\% have either a technical college or university degree, while less than $2 \%$ have attended a vocational training after the Abitur (category 4) and even less do not have any further qualification (category 3). The benefit recipiency rate is highest for individuals whose educational attainment is unknown and for persons who do not have any degree $(7 \%)$. The lowest rate is attained from technical college $(2.5 \%)$ and university graduates (about 2.8\%). The highest rate of persons being out of sample is listed by individuals that belong to category 3 (about 23.5\%), while the lowest rate is listed by individuals that possess a vocational training degree but no university-entrance diploma (about 9\%). The hypothesis of skill upgrading is confirmed by the development of employment in different skill groups over time. Employment of individuals with university-like education grows almost monotonically and more than doubles between 1976 and 1997, while employment of individuals without vocational training degree decreases by a third (see figure 7 in the appendix).

About $8 \%$ of the individuals in our data set are foreigners, who have a higher benefit recipiency rate $(7.2 \%)$ and a higher percentage of persons being out of sample $(12 \%)$ than Germans. Astonishingly, the number of foreigners strongly declines during the 80 s and increases again in the 90s (see figure 8 in the appendix). About $60 \%$ of the

\footnotetext{
${ }^{20}$ The category unskilled is related to the position an individual holds in his current (if employed) or previous (if benefit recipient) job, while low-skilled refers to an educational attainment.

${ }^{21}$ However, it might be that apprentices quitting their job or being dismissed have no unemployment claims yet, which means that eventually their rate is underestimated.
} 
employed are men showing a slightly higher benefit recipiency rate than women and a somewhat lower rate being out of sample. Looking at the development over time reveals that, as expected, the participation of women has increased over time by about one third between 1976 and 1996 (see figure 8 in the appendix). The benefit recipiency rate for persons with children is higher while the rate of people being out of sample does not differ a lot. ${ }^{22}$ Looking at age, we find that from $21-45$ years the (5 year age) groups of employed are almost of equal size, declining afterwards. In the age category from 61 to 62 years, there are not many individuals left and the group size is only about $5 \%$ of the typical group size of other age groups. The rate of benefit recipients is relatively high for persons aged between 21 and 30 and for elderly people between 51 and 60, while the rate of people being out of sample is highest for individuals between 26 and 30 (maybe women in pregnancy) and almost monotonically decreasing afterwards. Regarding the development over time, several aspects can be seen. First, individuals enter the labor market in the 90s much later than 20 years ago, with only half as many still entering between 16 and 20. Second, the number of old employees increases strongly at the end of the 90s. However, there is no clear cut trend of an ageing workforce. The number of young individuals seems to be highest at the beginning of the 90s. Finally, regarding wages, the benefit recipiency rate decreases as expected with the previous wage and so does the rate of persons being out of sample.

Let us turn to the cyclical behavior of the transition rates. Figure 3 shows the percentage of individuals who changed their job during one year relating to all individuals employed at the beginning of the year ${ }^{23}$ There is a cyclical structure for job-to-job transitions and the rate is positively related to real GDP growth (correlation coefficient 0.45 ), whereas the correlation between the rate of persons who remain in the same establishment with the business cycle is weaker (0.21) ${ }^{24}$ Allowing that last year's growth might influence today's job changing rate shows that after one year the positive correlation is even stronger (0.51). Figure 4 reveals that the transition rate from employment to benefit recipiency is countercyclical, as confirmed by the negative correlation coefficient $(-0.38) .{ }^{25}$ This negative correlation is even stronger if we allow for a lag, i.e. the transition rate to benefit recipiency is correlated to the growth rate of the previous year (-0.53). After two years the correlation becomes weaker. This negative correlation is in accordance with the literature (see e.g. Burda and Wyplosz (1994) for four European countries and Davis and Haltiwanger (1999) for the US). Transitions

\footnotetext{
${ }^{22}$ We doubt, however, that these numbers are correct, since there is a break in the data between 1989 and 1990. So the number of employees with children in 1991 is about one tenth of the number in 1989 .

${ }^{23}$ A potential shortcoming of our analysis of job-to-job transitions is, that we observe changes of the establishment and not of the firm. Under the hypothesis that internal labor markets work more or less similar to external labor markets, this is not a big shortcoming.

${ }^{24}$ In contrast to our results, Fallick and Fleischman (2001) conclude for the United States, that jobto-job transitions are not procyclical. Our numbers and theirs, however, are not directly comparable, since we relate the flows to the size of total employment, which might be responsible for the cyclical behavior.

${ }^{25}$ Excluding (in part unrealistic) values from the 70 s even leads to a correlation coefficient of -0.76 .
} 
from benefit recipiency to employment are practically not related to GDP growth. The lagged transition rate, though, is strongly positively related with GDP growth (0.54), but after two years the correlation has vanished. The correlation with the outflow rate from benefit recipiency is weakly positive $(0.18){ }^{26}$ It seems that layoffs and/or quits with a subsequent benefit recipiency spell are countercyclical in contrast to hirings being procyclical (all transitions to employment). The outflow rate from employment is countercyclical as indicated by a correlation coefficient of -0.2 , thus the probability to remain employed is procyclical (see table 4 in the appendix). The fact that we have the countercyclical structure for job separations is in accordance with the view that a downturn might have a cleansing effect in the sense that unproductive jobs are destroyed. It has to be noted, however, that job-to-job transitions are a means of improving match quality, which does not happen in a downturn, but in an upturn.

Now, we turn to the differences across demographic groups ${ }^{27}$ Table 3 in the appendix shows the labor market transition rates across all demographic groups. We observe three states and four transitions for each of the three states, since there is one state that indicates that an individual has left the data set and that he does not return any more. In addition, we observe one additional rate for the group of the employed, namely the transition rate from job to job.

Table 2 shows that on average about $8 \%$ of the previously employed change jobs, while about $3 \%$ become benefit recipients, and further $3 \%$ move out of sample. A bit more than $3 \%$ leave the data set (e.g. because of retirement, death, or business startups), while on average a bit more than $80 \%$ stay with the same employer or experience recalls. Hence with only about $20 \%$ of all workers leaving their current job per year, the German labor market exhibits higher employment stability than the US labor market where this number is about $37 \%$. Between one and two percent of the about $88 \%$ who remain employed in two consecutive years have an intervening benefit recipiency spell and another one to two percent have an intervening spell out of sample (not in the table). Once individuals are benefit recipients, they are employed again in the next year at a rate of $25 \%$. Similarly, about $25 \%$ return to employment when they are out of sample. About $40 \%$ of the benefit recipients are benefit recipients in the next year, while about $15 \%$ change to the state out of sample and another $15 \%$ leave the data set. Individuals that are out of sample remain in more than $65 \%$ of the cases in this state in the following year, while about 10\% either become benefit recipients (probably with an intervening employment spell) or leave the data set (with an intervening spell of either employment or benefit recipiency).

Search theory argues that individuals draw i.i.d. wage offers from some wage offer

\footnotetext{
${ }^{26}$ Here, Burda and Wyplosz (1994) and Davis and Haltiwanger (1999) conclude for the outflows from unemployment that they are countercyclical. Again, the differences to our results might come from the fact that we normalize by the number of unemployed, which might be responsible for the weakly procyclical behavior in our data set.

${ }^{27}$ Note that the (weighted) mean of the transition rates for those demographic characteristics which can change over time is not necessarily equal to the transition rate over all individuals, since we include in our analysis only individuals that maintain the same characteristics in two consecutive years.
} 
distribution at a constant rate. If individuals earn higher wages, wage offers exceed their earned wage more rarely, i.e. the job changing rate decreases with wage. Looking at table 3, where we separate the wage distribution into three crude wage categories of equal interval size (low, middle, and high wages), clearly confirms this argument. The risk of becoming benefit recipient or changing to the state out of sample shows similar patterns and declines with age. Likewise, the frequency at which individuals stay with the same employer increases with the wage. The transition rate from benefit recipiency to employment and probability of remaining benefit recipient is highest for intermediate wages. The transition rate to employment is higher for low wages than for high wages. While individuals with low wages comparatively often change to the out of sample state, high-wage individuals often leave the data set completely. The transition rates from out of sample to other states do not differ much.

Table 3 shows pronounced differences across age groups. Economic theory predicts that older individuals are on average in a better position in the wage distribution so that they accept wage offers from competitors more rarely. Therefore, we expect that the job changing rate declines with age. This is confirmed by the data ${ }^{28}$ Suitably, the frequency with which individuals stay with the same employer increases from age 20 to age 50 and declines afterwards. The benefit recipiency risk is high for young individuals up to 30 years and for elderly people from 56 onwards. The risk of moving out of sample is highest for individuals aged 21 to 25 and decreases afterwards, while obviously the probability of leaving the data set is very high for people aged 56 and older. The transition rate from benefit recipiency to employment is highest for individuals between 21 and 25 and decreases monotonically with age afterwards. The frequency at which individuals remain unemployed in two consecutive years increases from $47 \%$ for the 21 to 25 age group to $58 \%$ for the 51 to 55 age group and then decreases rapidly. The transition probability to the state out of sample is high until age 35 and decreases afterwards, while the probability of leaving the data set starts to increase from age 36 onwards. The outflow rate from the state out of sample decreases continuously with age, while the probability to remain out of sample decreases from age 20 onwards. The inflow rate into benefit recipiency increases monotonically up to age 60 and the probability to leave the data set is particularly high for the elderly. Since unemployment-to-job transitions are rarer for older individuals, search frictions seem to be higher for this group, while the job destruction rate declines at least up to age 50 indicating less frictions. In Fitzenberger and Garloff (2005), we distinguish transition rates for primeage working male by age and education. There are pronounced differences across age and education groups which are mostly in accordance with the search theoretic framework.

In the literature, education is an important determinant of economic outcomes. How-

\footnotetext{
${ }^{28}$ Farber (1999) presents the fact that the job-to-job transition rate declines with tenure. This is consistent with our observation on the behavior of this rate with age if older persons have on average longer tenures, which is always true if the job offer rate for unemployed is higher than the job offer rate on the job plus the job destruction rate.
} 
ever, simple equilibrium search theory does not make clear predictions on the effect of education on transition rates. From table 3 we see that the job changing rate increases with educational attainment. While medium-skilled individuals are more likely to stay with the same employer, high-skilled individuals are more likely to change jobs. Clearly the benefit recipiency risk and the risk of becoming out of sample is highest for low-skilled individuals and decreases with educational attainment. High-skilled individuals are most probable to vanish from the data set, eventually because they are more likely to become self-employed ${ }^{29}$ Once a benefit recipient, the job finding rate increases with education as well, although university graduates seem to have a somewhat lower rate than the medium-skilled. Individuals without any degree have by far the highest probability to remain unemployed in two consecutive years. If individuals are out of sample, their transition rate to employment increases with education, while the transition rate to benefit recipiency and the probability to remain out of sample decrease with education. Summing up, as expected, the situation is more favorable for the high-skilled, which means, in terms of search theory, that there are less frictions for the highly educated.

Regarding gender differences, women stay more rarely with the same employer over two consecutive years, while all other transition rates are a bit higher (see table 3). If women are benefit recipients, they remain less often in this state than men $(34 \%$ versus $48 \%$ ), since they show more frequent transitions to out of sample and to leaving the data set. Once women are out of sample, they remain so more often than men do (69\% versus 60\%) with all other rates being lower. Germans seem to be better off in the labor market exhibiting a higher probability to change jobs as well as to remain in the same job and lower probabilities to move to benefit recipiency, out of sample, or to leave the data set. For benefit recipients the differences are not large, but Germans are more likely to return to employment. In the state out of sample, foreigners have a slightly higher probability to become employed or benefit recipient and to leave the data set. At the same time, they show a lower probability to remain out of sample. Since we suspect that marital status is subject to measurement error, we do not discuss differences here.

Evidence regarding the professional status shows that especially clerks often change jobs. This might be due to scale effects of markets, since clerks are the biggest group and since therefore it might be easier to get in contact with a new job. In contrast, foremen are the least mobile group and they stay most often with the same employer. Unskilled workers have the highest benefit recipiency risk, while again foremen have the lowest risk. Apprentices and part-time employed most often change to the state out of sample. Part-time employed also leave the data set fairly often. The highest transition rate from benefit recipiency to employment is found for clerks. Again, this

\footnotetext{
${ }^{29}$ Another explanation might be that high-skilled married couples can afford that only one person works, since they obtain higher wages. Hence, if high-skilled individuals are often married to other high-skilled individuals, after marriage they vanish more often from the data set.
} 
might be due to scale effects ${ }^{30}$ Unskilled workers and craftsmen are most likely to remain unemployed in two consecutive years, while clerks have the lowest probability. Foremen show the highest propensity to leave the data set and most frequently return from the state out of sample to employment, while they remain rarely in this state in two consecutive years.

In the service sector job-to-job transitions are most frequent, but they are also frequent in commerce and traffic. Again, this might be due to scale effects. Basic industry has by far the lowest job-to-job transition rate and the highest rate to stay in the current job. In durable goods production and social insurances, the stayer rate in the current job is also high, while it is low in the construction sector and in the service sector. Benefit recipiency risk is high in the construction and in the consumer goods sector. In the service sector as well as in the construction sector and commerce, people often switch to the state out of sample. Farmers and employees in the social insurance or traffic sector often leave the data set completely. Once being benefit recipient, former employees in the construction or service sector are most likely to find a new job in this sector within the next year. Farmers and employees in the social insurance sector are most likely to remain benefit recipients, while this likelihood is lowest for the commercial sector. Benefit recipients from the service sector are most likely to change to the state out of sample, while benefit recipients from the consumption goods sector, the durable goods and basic goods sectors often leave the data set completely. Transition rates from out of sample to employment do not vary much, whereas the transition rates from out of sample to benefit recipiency state are high for the farming and construction sectors and low for services and the commercial sector.

Concluding, we find clear differences in almost all characteristics that we have looked at. Some differences can be explained in terms of economic theory, whereas others cannot. It is important to take account of these differences. Differences across characteristics indicate differences in the degree of frictions, which can explain differences in economic outcomes.

\subsection{Wage Changes following Job-to-Job Transitions}

This section explores the effect of job-to-job transitions on wages. This is important for several reasons and there exists a large body of literature on the effect of seniority on wages (see e.g. Dustmann and Meghir (2005)) ${ }^{31}$ It is often argued that due to accumulation of specific human capital wages increase with tenure 32 A contrary position argues that tenure effects are the result of shifts in the composition of employment. High-wage jobs are more likely to survive, so that we observe that long tenures and

\footnotetext{
${ }^{30}$ Petrongolo and Pissarides (2002) find in their analysis for the UK that scale effects are reflected in higher wages and not in more matches, since the reservation wage of the individuals reacts on a higher job-offer rate.

${ }^{31}$ Recognize that seniority can be interpreted as a sequence of non-mobility decisions.

${ }^{32}$ This argumentation can be traced back to Becker (1964).
} 
high wages are correlated. Third, from the search theoretic perspective, with growing experience, individuals have received on average more job offers from competing firms, which might lead as well to job-to-job changes under wage gains (see Burdett and Mortensen (1998) for a theoretical model) or to higher wages in the specific firm if firms can counter wage offers from competing firms (see Postel-Vinay and Robin (2002a)) ${ }^{33}$ So the fact that we observe less job-to-job transitions and higher wages as people age might stem from the fact that they have acquired a lot of specific human capital which they would loose when changing jobs or from the fact that they simply have higher wages because of more offers from competing firms, so that on average job offers rarely exceed their wage. Recognize that, from this perspective, job-to-job transitions are the central source of wage growth and that they play a critical role in equilibrium search models. Almost all of the existing equilibrium search models that derive an endogenous wage distribution depend critically upon the fact that workers can search on the job 34

Both the effect of seniority on wages and effects of mobility on wages have been discussed intensively in the literature. The literature on mobility, though, is often motivated from a more geographical perspective. Regarding the interaction of mobility, human capital, and wages the literature is more narrow. Examples for studies addressing this problem in a non-structural way are Antel (1986), Light and McGarry (1998) and Garloff and Kuckulenz (2005). In the following, we analyze in detail the wage changes associated with a direct job-to-job transition, defined as a transition from one establishment to another within 15 days. Recall that the average annual job-changing rate lies just below $8 \%$. This might not exactly reflect the job-to-job changes we define here, since there might be individuals who change jobs and return to the previous employer afterwards (recalls) or individuals who change jobs and then become benefit recipients or move out of sample afterwards. Furthermore, there might be individuals who change jobs more than once within one year. We suspect, however, that the difference between the two definitions is not big. Moreover, as demonstrated above, these rates range from a minimum of less than $1 \%$ a year (for the age group 61-62 years) up to a maximum of just under 15\% (for the age group 21-25 years).

Overall, we observe about 360,000 direct job-to-job transitions over the 23 years and the development over time closely resembles its normalized measure in figure 3. On average, about $64 \%$ of the individuals gain from a job-to-job change, while about $29 \%$ experience wage cuts. ${ }^{35}$ Average gains for the $65 \%$ that have wage increases are quite high with an average gain of $41 \%$ relative to their previous wage. The average loss of the individuals suffering a wage cut is about $18 \%$. For all individuals this implies an average gain of $21 \%$ associated with a job-to-job transition. However, one has to be

\footnotetext{
${ }^{33}$ In addition, there might be a match-specific component that does not result from higher productivity but from better information about the match (see e.g. Moscarini (2003)).

${ }^{34}$ For an exception, see e.g. Acemoglu and Shimer (2000) where the decision problem is not sequential, and Teulings and Gautier (2004).

${ }^{35}$ This number is roughly comparable to the numbers that are found by Jolivet, Postel-Vinay, and Robin (2004) using the ECHP.
} 
careful when interpreting these numbers, since all types of transitions are included in the calculations. So, for example, we have included transitions from apprentices to their regular profession or people changing from part-time to full-time employment and vice versa. As a result, we probably overestimate both gains and losses $\sqrt[36]{6}$ We use different wage definitions to check for consistency (see appendix A.5). Since the differences are not big, we use in the following the first wage definition (wage A) where wages are deflated and where we replace censored wages by their conditional expectations from Tobit-estimates.

In table 6, we distinguish job-to-job transitions for the group of full-time employed, according to the working time in the subsequent job. The bulk of transitions is within the group of full-time employees. The results are broadly consistent with the wage change being a crucial determinant of the decision to change a job, as purported by search theory. In general, individuals gain considerably from job-to-job transitions. But, even within the category of full-time employees, there remains a significant proportion of job changers with wage cuts. This is difficult to reconcile with standard search theory, although more advanced theoretical models are able to explain this (see Jolivet, Postel-Vinay, and Robin (2004) or Postel-Vinay and Robin (2002b)) 37 Probably, most job-to-job transitions from full-time to part-time are not motivated by the desire to improve upon the wage but by other reasons (as e.g. the birth of a child). Among these transitions, the share of winners shrinks to $45 \%$ (respectively, to $25 \%$ for individuals who change to half or less than half of regular time), while the share of losers increases to $53 \%(71 \%)$. It is quite remarkable that the relative gains of those who win increases to about $50 \%(48 \%)$. So does the relative loss of losers. It remains an open question as to why the winners who work less gain on average considerably more 38 Changing to part-time with more than half of the regular time results on average in a small wage gain $(+7.7 \%)$, while individuals who change to half or less than half of regular time lose on average $22 \%$. As a final caveat, one should not overinterpret these results because full-time/part-time variable is likely to be subject to measurement error. There is nothing, we can do about this in our study.

Table 7 shows the differences across movers within categories. If we omit apprentices from the analysis of transitions within the group of full-time employees, the share of winners is a bit lower and the share of losers is a bit higher than for all full-time

\footnotetext{
${ }^{36}$ We repeated the procedure using the CPI to deflate wages, but the results were so similar that we do not report them here.

${ }^{37}$ In the first model, they introduce a new sort of shocks, so called reallocation shocks, which force individuals to change jobs irrespective of the wage offer they get. The basic idea in the second model is that people change jobs since they have better career opportunities in the new establishment, which makes them accept wage losses. In the literature, the empirical findings for the share of individuals who accept wage losses are quite different. Van den Berg and Ridder (1998) find a very small number for the Netherlands (about 11\%; OSA-panel) which they interpret as measurement error, while PostelVinay and Robin (2002b) find a much larger number (between 36\% and 55\%, DADS-panel) for France.

${ }^{38}$ However, a part of these high-wage gains is explained by the fact that we have included apprentices in the analysis. Furthermore, some of this high-paying part-time jobs are very transitory in the sense that they only last some days.
} 
employed individuals. Still, the share of winners is somewhat below two thirds and the share of losers under $30 \%$, while about $7 \%$ do not experience a wage change when changing jobs (probably in many cases censored values). Excluding apprentices, the average relative gain of the winners decreases clearly from about $40 \%$ (table 6) to about $25 \%$. So does the average relative loss of the losers which decreases from around 17\% (table 6) to around 15\%. The overall gain amounts to just under 13\%. Among part-timers, who work less than half of the regular time, there are fewer winners, while in the group of more than half part-time employed average gains and losses are comparatively small. As to be expected, changing to full-time employment is associated with the highest average wage changes.

Next, we separate job-to-job changes by terciles (see table 8 in the appendix) of the conditional distribution of the initial wages (on age, education and year) for full-time employed West-German individuals without multiple employment spells. As predicted by search theory, the share of winners is highest $(+75 \%)$ in the low wage tercile, similar to $+68 \%$ in the middle wage tercile and much lower in the upper wage tercile $(+44 \%)$. However, adding the share of individuals without a wage change shows that differences might be smaller, because in the upper tercile, where censoring is a severe problem, about $22 \%$ do not experience a wage change, while in the other terciles this amounts only to around $3 \% .39$ The share of losers increases with the wage tercile. The average gain of the winners is - as expected - the highest in the low wage tercile (around 40\%), while it is around $17 \%$ for the two higher wage terciles. The average loss of the losers is much higher for employees from the upper tercile compared to the two lower terciles 40 Overall, the evidence is in accordance with search theory.

Across age categories, the share of winners declines from about $71 \%$ for the age group 16-20 (excluding apprentices) to about 53\% for the oldest age group. For the share of losers there is no such clear-cut development. With about $30 \%$, the share of losers is highest for the age categories 20 and 35 and again for the oldest age group, while between age 35 and 60 it decreases. Relative gains are quite high for the youngest age group and then decline with age from about $50 \%$ to $16.5 \%$. The same holds for the losses, but they do not vary as much as the relative gains (from $18 \%$ for the youngest to $13 \%$ for the oldest). Controlling for the position in the wage distribution partly eliminates this effect. It disappears for the high and the middle tercile, while it is still present for the low-wage tercile (results are omitted here).

Next, we summarize differences through regressions focussing on prime-age (25-54 years) working males. Table 10 shows how the share of winners and losers varies

\footnotetext{
${ }^{39}$ Job changes for individuals whose wages are censored before will very often result in a censored wage observation afterwards indicating no wage change, see section 3 for the imputation of wages in the case of censoring.

${ }^{40}$ If job-to-job changes under wage cuts are interpreted as reallocation shocks, as in Jolivet, PostelVinay, and Robin (2004), then the higher wage loss for higher wage categories is the wage ladder effect, since after being reallocated, individuals obtain offers from the same wage offer distribution which means that the loss for high-wage individuals is higher.
} 
by age and education. The share of winners increases with educational attainment and age ${ }^{41}$ The share of losers is lower, the higher the educational attainment, while there is no clear age effect. But the share of losers is on average lower for older individuals than for younger individuals. While the relative gain of winners is negatively related with the share of winners, this is not the case for the share of losers. From this, we conclude that age seems to have a significant impact on the motivation for a job-tojob change decision, with wage gains losing importance as individuals age. Table 11 summarizes the relationship between the relative gain of the winners and the relative loss of the losers, by age and education. We find that high-skilled individuals have significantly higher gains and lower losses than low-skilled; maybe because voluntary job-to-job changes in this category are more frequent. The medium-skilled do not differ significantly from the low-skilled. The relative gain of the winners decreases with age, which is in accordance with search theory, but there is no age effect on the relative loss. The latter indicates that job-to-job changes under wage losses are not driven by economic reasons. An exogenous job loss and a new random offer from the wage offer distribution would imply that the relative loss increases with age. The share of winners is again negatively correlated with the relative gain of the winners, while the share of losers is positively related to the relative loss of the losers.

Now, we include the tercile position in the conditional wage distribution in the regressions (tables 13 and 14). The position in the wage distribution has the expected effect on the shares and the relative gain/loss and seems to reduce considerably the effect of education and age. Indeed, based on search theory, age should not show an independent effect on the share of winners. But, we find that controlling for the wage position changes the signs for the mostly significant age dummies and there is no clear cut trend across age groups. The average age effect is positive for the share of winners and not different from zero for the share of losers. For the relative gain, as expected, we find that it is lower for individuals in higher wage categories and that it increases with educational attainment. As before, age has on average a negative effect on the relative gain and a positive effect on the relative loss.

Furthermore, we examine wage changes after an intervening benefit recipiency spell and categorize their duration into five intervals (table 9 in the appendix). First, most unemployment spells are very short, i.e. shorter than 3 months, or very long, i.e. longer than a year. The share of winners as compared to their last wage decreases with benefit duration. While it is about $55 \%$ of the short-term unemployed, only $40 \%$ of the longterm unemployed have a higher wage. Accordingly, the share of losers increases with benefit duration. Surprisingly, however, the relative gain of winners rises with benefit recipiency duration and so does the relative loss of losers. Regarding the relative gain of winners, longer search duration seems to improve the match quality, which again is in accordance with predictions from search theory. While the average change after a job-to-job transition for all individuals decreases with benefit duration, this is not the

\footnotetext{
${ }^{41}$ Note that the share of winners is likely to be too low for the upper tercile, see footnote 39
} 
case for the long-term unemployed. Here, the longer search period leads to a higher average wage in the job after the benefit phase.

Finally, we investigate the wage changes for individuals who changed jobs (within 15 days) and compare their wage growth in the following four years with individuals without a job-to-job transition in the first year (table 12 in the appendix). The results are not clear cut. From 1975 to 1983, the wage growth for changers is remarkably higher than for stayers in the first year and the difference decreases over time. Two years after the job change, there is no difference. After 1983, however, job changers are not in a better position anymore. In some years it even seems that job changers are in a worse position than job stayers, possibly reflecting compositional effects.

Summing up, wages seem indeed to play a crucial role for job-to-job changes, in accordance with search theory. On average, almost all changes involve remarkable average wage gains. Notwithstanding non-monetary motives, job-to-job changes appear to advance one's career through higher wages. However, a significant proportion of jobto-job changes are associated with wage losses. While layoffs associated with finding a new job immediately might account for part of these wage losses, it is unlikely that such a high share of wage losses can be attributed to this effect alone or to measurement error (as in Van den Berg and Ridder (1998)). Here, an investment motive anticipating later career opportunities as in Postel-Vinay and Robin (2002b) or in Burdett and Coles (2003) seems more appealing. Furthermore, there are pronounced differences between different demographic groups (which we do not discuss here), that are not easily explained by economic theory, and there are differences for full-time and part-time employed. Thus, noneconomic factors are likely to influence the decision to change a job. In accordance with search theory, the frequency and the size of wage gains are highest for workers in the lower part of the wage distribution conditional upon age, education, and year.

\subsection{Wage Structure and Changes in the Relative Wage Posi- tion}

This section analyzes the wage distribution for different groups and the determinants of changes in the relative wage position ${ }^{42}$ First, figure 9 and 11 show the distribution of (log-) wages in a cross section of individuals on 1 January 1986 for all full-time employed individuals (excluding apprentices, 9) and for clerks only (11). For comparison reasons, figures 10 and 12 display the distribution of log-wages for clerks in 1976 and 1996. The distribution of log-wages does not appear (censored) normal because of the thin left tail. Kolmogorov-Smirnov-tests confirm this: for each partition of the sample, we reject the hypothesis that log-wages are normally distributed. Furthermore, considering the distribution of wages in (homogeneous) age-education cells, search theory suggests that wages should be skewed to the left, which is also rejected by a visual inspection.

\footnotetext{
${ }^{42}$ For an extensive treatment of wage changes, see Pfeiffer (2003).
} 
Here, the analysis is restricted to employees who are employed in two successive years. Our interest is on career advancements and its determinants, especially job-to-job transitions. We take this group of individuals, define their position in the wage distribution in the first year (measured in deciles) and observe which decile position they hold in the next year, depending on their characteristics. For each group of individuals, a 10x10-Matrix captures the transitions in the decile position. Then, we aggregate this information in an ordered Probit model allowing for the three outcomes upward, no change, or downward mobility in the decile position. As before, censored wages are replaced by their conditional expectation. If an individual's wage is censored, we observe the individual in the decile of the wage distribution where we observe censoring for the first time coming from below, i.e. when the sixth decile is the first censored decile (that is, more than $40 \%$ of the wages are censored, which is often the case for the highskilled group aged 31-33), all individuals are observed in this decile. If an individual's wages are censored in two consecutive years, we will observe no wage change if the first censored decile is the same in the two consecutive years (the most plausible case). In the case where the first censored decile is lower (higher) than in the previous year, say the fifth, we interpret this as wage cuts (increases) for all censored individuals.

We start with the ordered Probit model in table 15 based on those individuals who are employed in two consecutive years. The dependent variable is 1 if an individual moves up by one or more deciles of the wage distribution, it is 0 if the individual stays in the same decile, and it is -1 if the individual moves down by one or more deciles. For this analysis, we include only prime-age males in the age group 25 to 54 years, disaggregated in three year age intervals. Among others, the set of covariates in table 15 includes the interquartile range in wages, the rate of job changes, and the stayer rate in employment by age-education cell, as well as a dummy for a job-to-job transition at the individual level (different employers in the two consecutive years).

The age-education cell with the lowest age and the lowest education level and the year 1975 is chosen as omitted category. The probability of climbing the wage ladder decreases significantly in age and increases in the skill level. This result is in accordance with search theory. The dummy variable for job-to-job transition is also highly significant and positive, thus job-to-job transitions involve upward wage mobility as predicted by search theory 43 The impact of the cell specific variables, the wage dispersion measure (iqr), the transition rate from job-to-job, and the retention rate in employment is difficult to predict. It seems plausible that a higher wage dispersion is favorable for upward wage mobility, since the return to search is higher. However, our results show that the effect of the wage dispersion measure is small and the point estimate is negative. Search theory also offers an alternative interpretation. If wage dispersion is high, then search frictions are large and we observe little (upward) wage mobility. This effect should work through a low job-to-job transition rate, which we

\footnotetext{
${ }^{43}$ Of course, the job change indicator is endogenous. However, from a search-theoretic perspective, it is irrelevant whether the job change takes place because the individual obtains a higher wage offer or whether the individual obtains a higher wage because he changes the job.
} 
account for in the analysis, and through the job destruction rate. The job-to-job transition rate is not significant, thus rejecting this argument. However, the retention rate in employment (三(1-job destruction rate) ) has a small but significantly positive effect on upward wage mobility. With a decreasing probability to remain employed, individuals might be more willing to accept wage cuts which is in line with the argument.

Table 16 shows a similar analysis replacing the year dummies with a linear time trend and allowing for interactions between job-to-job changes and age. The effects of age group and education category are similar in magnitude, although now the middleeducation group shows the highest propensity to have wage increases. The job change dummy effect is now somewhat larger, and we can see from the table that job-to-job changes have a smaller effect on the probability of having wage increases as individuals age. This is in accordance with search theory, since older individuals have on average a better position in the wage distribution, and therefore their propensity for upward wage mobility through job-to-job transition decreases. As argued before, it might be that a bigger share of job-to-job transitions are not economically motivated as individuals age.

Separate analyses for the different education groups and for job changers and stayers, the results do not differ much (see tables 17 and 18). However, for high-skilled workers we find that the effect of age on upward wage mobility is first positive and then negative, which can be due to university graduates entering the labor market later. Furthermore, the effect of age on the propensity for upward wage mobility shows a similar pattern for all education groups and for changers and stayers. It becomes stronger with higher education. For example, in the group of stayers, the coefficients for age range from -0.13 (28 to 30 years) to -0.29 ( 52 to 54 years) for the low-skilled and from +0.98 (28 to 30 years) to -1.58 (52 to 54 years) for the high-skilled. Interestingly, the effect of wage dispersion is positive for changers and stayers in the two lower education groups, while it is negative for the high-skilled, however, the latter results might be questionable because of censoring. The result for the high-skilled dominates the positive effects in the other wage groups when pooling the three education groups. For the stayer rate in employment, a similar pattern is found. While the coefficient for changers and stayers is negative for the two lower education categories, it is positive for the high-skilled. Again, the effect of the high-education category dominates the effect of the lower education groups. The effect of the job-to-job transition rate is insignificant for the two lower education groups, whereas it is significant and negative for the high-education group. This is a surprising result, since we would have suspected that a higher job changing rate corresponds to less frictions and faster upwards movements, thus favoring upward wage mobility.

Finally, we classify the group of individuals with transitions from unemployment to employment by the positions of their wage in the contemporaneous wage distribution before and after unemployment (see table 19). Based on these data, we perform the same analysis as before. The age profile shows a similar pattern as before for low-skilled 
and medium-skilled individuals. For the high-skilled, no such pattern is found and no coefficient is significant. The wage dispersion measure and the transition rate from employment to benefit recipiency are not significant in either model.

Summarizing our findings, job-to-job transitions are strongly related to wages. We find that age shows a strong negative effect on upward wage mobility. Elderly individuals are less likely to experience wage gains. The same holds for older individuals changing jobs: they gain less than their younger counterparts. This is in accordance with job search theory. Furthermore, education has a strong positive effect on upward wage mobility. A possible explanation could be that the informational situation is better for the high-skilled. Cell specific macro variables apparently do not have the same effect on the three education groups with different effects for the high-skilled. The partial correlation of the stayer rate in employment and the upwards wage mobility is positive for the low-skilled and the medium-skilled, for the high-skilled this correlation is negative. Similar results are observed for other macro variables.

\section{Conclusions}

Using equilibrium search theory as the theoretical background, this paper presents a descriptive empirical analysis exploring labor market dynamics and the wage structure in Germany. We find considerable differences in labor market transition rates over the business cycle and across demographic groups, which can partly be explained by search theory. Our analysis also explores the wage structure and determinants of wage changes. Wage changes following job-to-job transitions are quite remarkable and most job changes involve wage gains. There exists a considerable number of individuals who do not gain from job-to-job changes, which is unlikely to be explained solely by the fact that some individuals may be laid off and immediately find a new job, or by measurement error. This finding somehow contradicts the simple equilibrium search model, as outlined in the theoretical section.

Further findings are that, first, part-time employees gain less from job-to-job changes than full-time employees, which we cannot explain easily by economic theory. Second, job-to-job changes in the low-wage group often involve wage losses. We show that wages are neither log-normally distributed for either group we looked at, nor that the wages for a homogeneous age-education group are skewed to the left. This can be taken as prima facie evidence against equilibrium search theory, implying a wage distribution skewed to the right. Regarding upward wage mobility, age (negative) and job-to-job transitions (positive), as well as the interaction between the two (decreasing with age) show the expected relationship. Also, education effects appear to be in accordance with theoretical considerations. The effect of cell specific macro variables appear to vary across the education groups. High-skilled workers differ somewhat from the other groups. 
Clearly, the non-structural approach taken here does not suffice to evaluate a complex set of theories. Nevertheless, our comprehensive descriptive analysis provides some clear insights. One of the crucial aspects of equilibrium search theory, i.e. job-to-job transitions, shows a close relationship with wages and the wage distribution, mostly in accordance with theoretical considerations. Further research should evaluate the empirical content of equilibrium search theory for Germany in a more structural way. 


\section{References}

Abowd, J. M., F. Kramarz, and D. N. Margolis (1999): "High Wage Workers and High Wage Firms," Econometrica, 67(2), 251-333.

Acemoglu, D., and R. Shimer (2000): "Wage and Technology Dispersion," Review of Economic Studies, 67, 585-608.

Albrecht, J. W., and B. Axell (1984): "An Equilibrium Model of Search Unemployment," Journal of Political Economy, 92(5), 824-840.

Antel, J. J. (1986): "Human Capital Investment Specialization and the Wage Effect of Voluntary Labor Mobility," Review of Economics and Statistics, pp. 477-483.

Bachmann, R. (2005): "Labour Market Dynamics in Germany: Hirings, Separations, and Job-to-Job Transitions over the Business Cycle," Discussion Paper 2005-045, SFB 649, Berlin.

Becker, G. S. (1964): Human Capital. Chicago: University of Chicago Press.

Bender, S., A. HaAs, and C. Kloose (2000): "The IAB Employment Subsample 1975-1995," Schmollers Jahrbuch, pp. 649-662.

Bontemps, C., J.-M. Robin, and G. J. VAn den Berg (2000): "Equilibrium Search with Continuous Productivity Dispersion: Theory and Nonparametric Estimation," International Economic Review, 41(2), 305-358.

Burda, M. C., And C. Wyplosz (1994): "Gross Worker and Job Flows in Europe," European Economic Review, 38, 1287-1315.

Burdett, K., And M. Coles (2003): "Equilibrium Wage-Tenure Contracts with Heterogenous Firms," Econometrica, 71(5), 1377-1404.

Burdett, K., And K. Judd (1983): "Equilibrium Price Dispersion,” Econometrica, 51, 955-970.

Burdett, K., and D. T. Mortensen (1998): "Wage Differentials, Employer Size, and Unemployment," International Economic Review, 39(2), 257-273.

Davis, S. J., And J. Haltiwanger (1999): "Measuring Gross Worker and Job Flows," in Labor Statistics Measurement Errors, ed. by J. Haltiwanger, M. Manser, and R. Topel, chap. 3, pp. 77-119. Chicago: University of Chicago Press.

Diamond, P. A. (1971): "A Model of Price Adjustment," Journal of Economic Theory, 3, 156-168.

Dustmann, C., and C. Meghir (2005): "Wages, Experience and Seniority," Review of Economic Studies, 72, 77-108.

Fallick, B. C., and C. A. Fleischman (2001): "The Importance of Employer-toEmployer Flows in the U.S. Labor Market," unveröffentlichtes Manuskript, Federal Reserve Board, Washington. 
FARBer, H. S. (1999): "Mobility and Stability: The Dynamics of Job Change in Labor Markets," in Handbook of Labor Economics, ed. by O. Ashenfelter, and D. Card, chap. 37, pp. 2439-2483. Amsterdam et al.: Elsevier.

Fitzenberger, B., And A. Garloff (2005): "Unhemployment, Labor Market Transitions and Residual Wage Dispersion," Discussion Paper No. 05-04, Centre for European Economic Research (ZEW), Mannheim.

Fitzenberger, B., and F. Reize (2002): "Verteilung, Differenziale und Wachstum - Eine Verdienstanalyse Auf Basis der Gehalts- und Lohnstrukturerhebung," Discussion Paper No. 02-71, Centre of European Economic Research (ZEW), Mannheim.

Franz, W. (2003): Arbeitsmarktökonomik. Berlin et al.: Springer-Verlag, fifth, completely revised edn.

Garloff, A. (2003): "Lohndispersion und Arbeitslosigkeit: Neuere Ansätze in der Suchtheorie," Discussion Paper No. 03-60, Centre of European Economic Research (ZEW), Mannheim.

Garloff, A., and A. Kuckulenz (2005): "Training, Mobility, and Wages: Specific versus General Human Capital," unpublished manuscript, Centre for European Economic Research, Mannheim.

Gautier, P., And C. N. Teulings (2003): "How Large are Search Frictions?," Discussion Paper No. 3861, Centre for Economic Policy Research(CEPR), London.

Jolivet, G., F. Postel-Vinay, and J.-M. Robin (2004): "The Empirical Content of the Job Search Model: Labor Mobility and Wage Distributions in Europe and the U.S.," mimeo.

Light, A., And K. MCGarry (1998): "Job Change Patterns and the Wages of Young Men," Reviwe of Economics and Statistics, pp. 276-286.

Moen, E. R. (1999): "Education, Ranking and Competition for Jobs," Journal of Labor Economics, 17(4), 694-723.

Mortensen, D. T. (2003): Wage Dispersion. Why are Similar Workers Paid Differently?, Zeuthen Lecture Book Series. Cambridge/London: MIT.

Mortensen, D. T., And C. A. Pissarides (1994): "Job Creation and Job Destruction in the Theory of Unemployment," Review of Economic Studies, 61, 397-415.

Moscarini, G. (2003): "Job Matching and the Wage Distribution," Econometrica, $73(2), 481-516$.

Petrongolo, B., and C. A. Pissarides (2002): "Scale Effects in Markets with Search," Discussion Paper No. 3648, Centre for Economic Policy Research (CEPR), London.

PFEIFFER, F. (2003): Lohnrigiditäten in gemischten Lohnbildungssystemen. BadenBaden: Nomos. 
Pissarides, C. A. (2000): Equilibrium Unemployment Theory. Cambridge (Massachusetts): MIT Press, 2nd edn.

Postel-Vinay, F., And J.-M. Robin (2002a): "The Distribution of Earnings in an Equilibrium Search Model with State-Dependent Offers and Counter-Offers," International Economic Review, 43(4), 989-1016.

(2002b): "Equilibrium Wage Dispersion with Worker and Employer Heterogeneity," Econometrica, 70(6), 2295-2350.

Statistisches Bundesamt (ed.) (2000): Statistisches Jahrbuch 2000 für die Bundesrepublik Deutschland. Stuttgart: Metzler-Poeschel.

Stevens, M. (2004): "Wage-Tenure Contracts in a Frictional Labour Market: Firms' Strategies for Recruitement and Retention," Review of Economic Studies, 71(2), $535-551$.

Stigler, G. J. (1961): "The Economics of Information," Journal of Political Economy, 69(3), 213-225.

Teulings, C. N., And P. A. Gautier (2004): "The Right Man for the Job," Review of Economic Studies, im Erscheinen.

VAn den BerG, G. J., And G. Ridder (1993): "Estimating an Equilibrium Search Model from Wage Data.," in Panel Data and Labour Market Dynamics, ed. by H. Bunzel, P. Jensen, and N. Westgard-Nielsen, vol. 222 of Contributions to Economic Analysis, pp. 43-55. Amsterdam et al.: Elsevier.

(1998): "An Empirical Search Model of the Labor Market," Econometrica, 66(5), 1183-1221. 


\section{A Appendix}

\section{A.1 Abbreviations}

1. Labor market states:

(E) employed

(BR) recipient of transfer payments (i.e. unemployment benefits, unemployment assistance and income maintenance during participation in training programs) (OOS) out of sample

2. E-EO is the share of individuals who change jobs between two consecutive years.

3. $\mathrm{E}-\mathrm{E}$ is the share of individuals who are employed in the first year and still (or again) employed in the second year.

4. $\mathrm{U}-\mathrm{E}$ is the share of individuals who are unemployed in the first year and employed in the second year. 


\section{A.2 Average stocks and transitions rates across demographic groups}

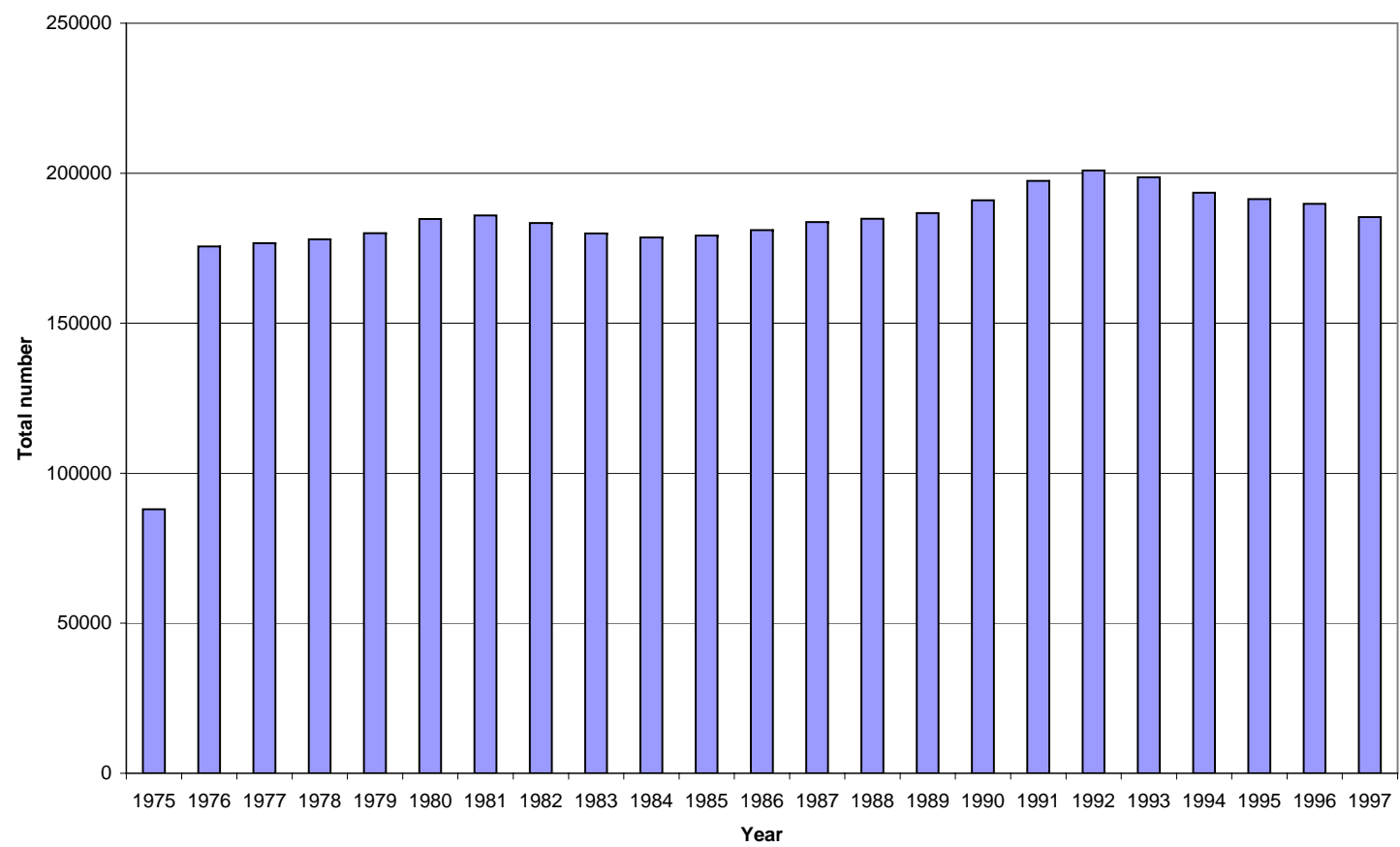

Figure 1: Number of employed individuals

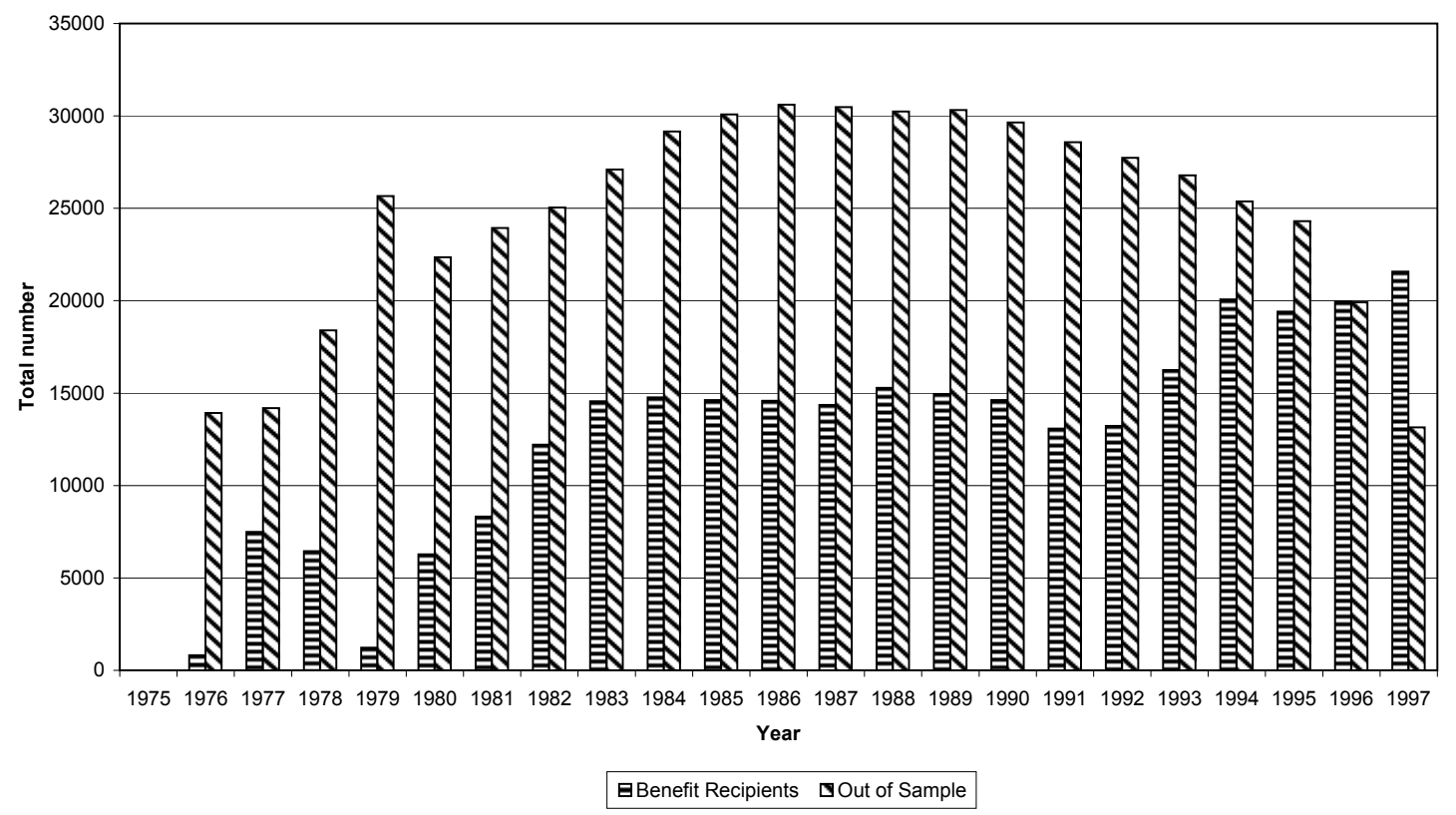

Figure 2: Total number of benefit recipients and individuals that are temporarily not in the data set 


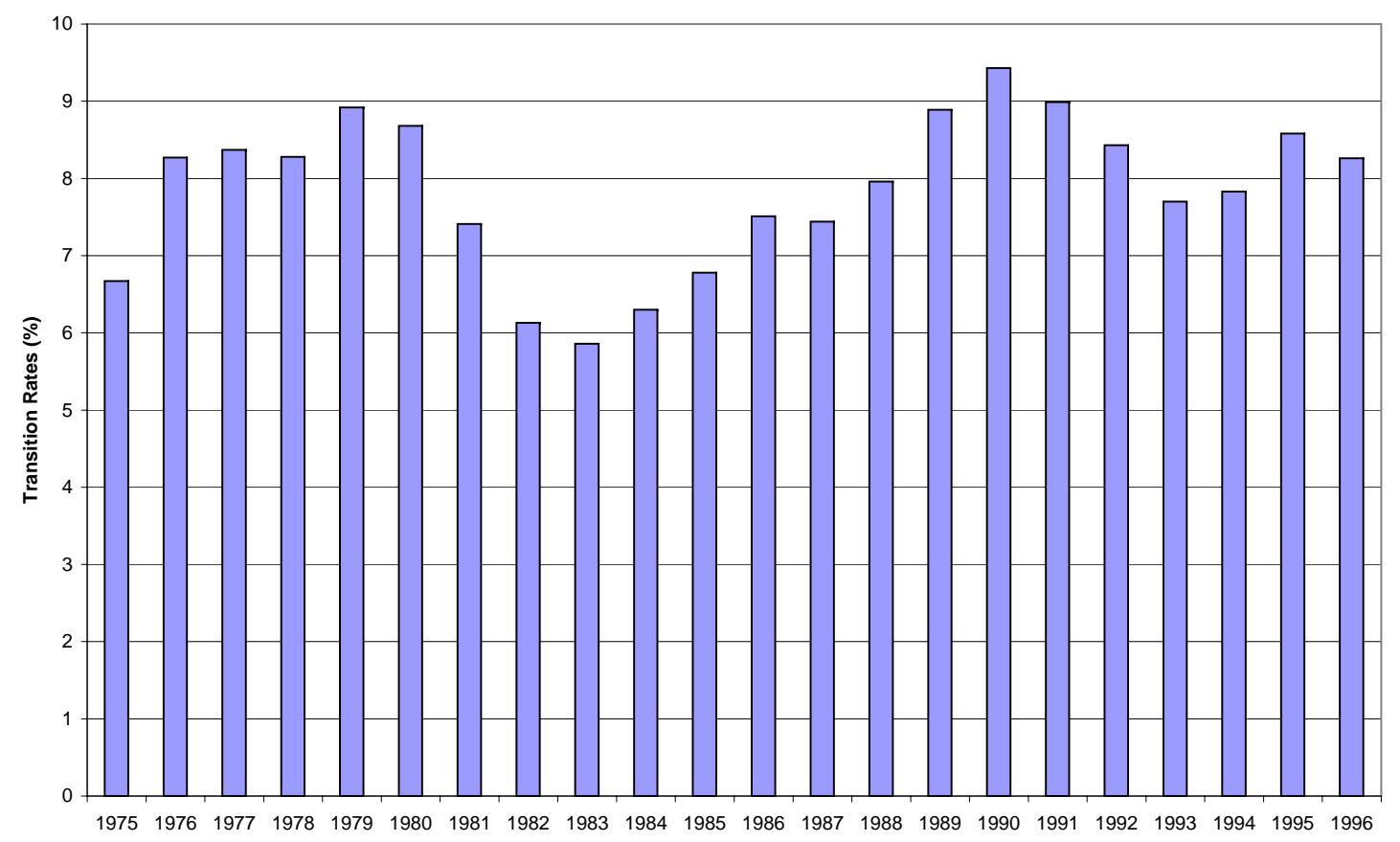

Figure 3: Job-to-job transitions as percentage of employment

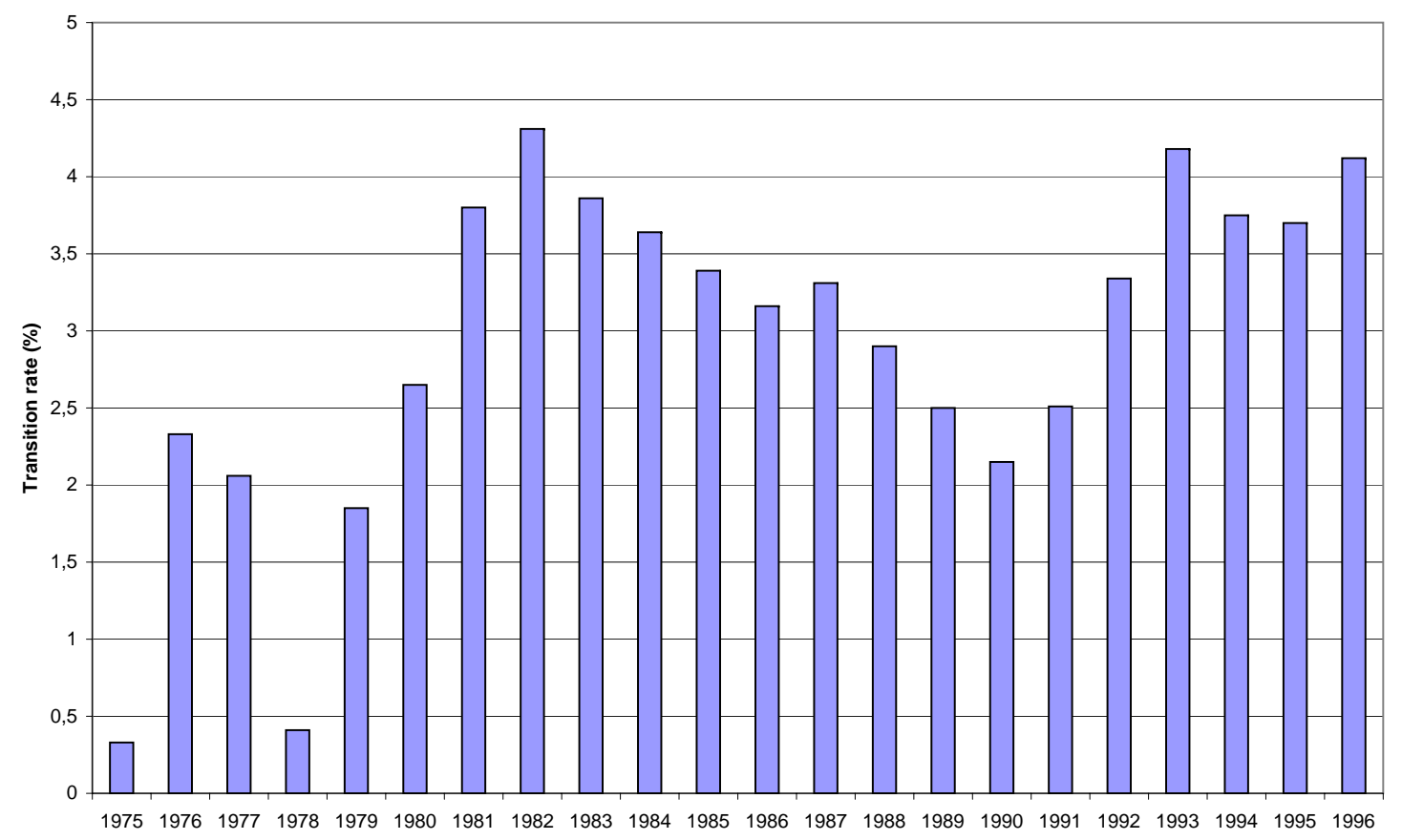

Figure 4: Transition rate from employment to benefit recipiency 
Table 1: Stocks across different characteristics

Characteristic

Employed Benefit Out of Benefit Out of Total recipient sample recipient sample

rate rate

\begin{tabular}{|c|c|c|c|c|c|c|}
\hline All & 181486 & 12354 & 23782 & 0.057 & 0.109 & 217622 \\
\hline \multicolumn{7}{|l|}{ Sectors } \\
\hline Main construction trade & 8233 & 1077 & 1008 & 0.104 & 0.098 & 10318 \\
\hline Construction (upgrading) & 4978 & 460 & 587 & 0.076 & 0.097 & 6025 \\
\hline Farming, energy, mining & 5664 & 378 & 524 & 0.058 & 0.080 & 6566 \\
\hline Services (business) & 16405 & 1588 & 3173 & 0.075 & 0.150 & 21166 \\
\hline Services (household) & 7237 & 802 & 2108 & 0.079 & 0.208 & 10148 \\
\hline Services (society) & 22403 & 1078 & 4284 & 0.039 & 0.154 & 27765 \\
\hline Food/stimulants industry & 6115 & 410 & 815 & 0.056 & 0.111 & 7340 \\
\hline Basic goods production & 14392 & 989 & 907 & 0.061 & 0.056 & 16288 \\
\hline Commerce & 25481 & 1653 & 3995 & 0.053 & 0.128 & 31129 \\
\hline Producer durable good prod. & 36198 & 1882 & 2578 & 0.046 & 0.063 & 40659 \\
\hline Social Security/local auth. & 11996 & 577 & 1206 & 0.042 & 0.088 & 13778 \\
\hline Consumer goods & 14016 & 974 & 1312 & 0.060 & 0.080 & 16302 \\
\hline Traffic/telecommunication & 8222 & 448 & 1243 & 0.045 & 0.125 & 9913 \\
\hline Missing & 144 & 37 & 42 & 0.167 & 0.190 & 224 \\
\hline \multicolumn{7}{|l|}{ Marital status } \\
\hline Single & 81578 & 5739 & 13182 & 0.057 & 0.131 & 100499 \\
\hline Married & 94102 & 6573 & 10252 & 0.059 & 0.092 & 110928 \\
\hline Missing & 5805 & 42 & 348 & 0.007 & 0.056 & 6195 \\
\hline \multicolumn{7}{|l|}{ Professional status } \\
\hline Apprentices & 12927 & 466 & 1429 & 0.031 & 0.096 & 14823 \\
\hline Clerks & 69483 & 2869 & 7290 & 0.036 & 0.092 & 79642 \\
\hline Skilled Workers/Craftsmen & 39337 & 2808 & 2988 & 0.062 & 0.066 & 45133 \\
\hline Unskilled Workers & 37985 & 4406 & 5977 & 0.091 & 0.124 & 48368 \\
\hline Masters/Foremen & 3414 & 131 & 152 & 0.035 & 0.041 & 3697 \\
\hline Home Workers & 332 & 32 & 87 & 0.071 & 0.192 & 451 \\
\hline Part-Time Workers ${ }^{(a)}$ & 3085 & 49 & 1565 & 0.010 & 0.333 & \\
\hline Part-Time Workers ${ }^{(b)}$ & 14881 & 845 & 4186 & 0.042 & 0.210 & \\
\hline Missing & 42 & 748 & 107 & 0.833 & 0.120 & 897 \\
\hline \multicolumn{7}{|l|}{ Education } \\
\hline Category $1^{(c)}$ & 48792 & 4039 & 6066 & 0.069 & 0.103 & 58897 \\
\hline Category $2^{(d)}$ & 107614 & 5771 & 10989 & 0.046 & 0.088 & 124375 \\
\hline Category $3^{(e)}$ & 1835 & 79 & 592 & 0.031 & 0.236 & 2506 \\
\hline Category $4^{(f)}$ & 3295 & 122 & 652 & 0.030 & 0.160 & 4068 \\
\hline Polytechnic & 4115 & 123 & 757 & 0.025 & 0.152 & 4995 \\
\hline University & 50059 & 183 & 1432 & 0.028 & 0.216 & 6620 \\
\hline Unknown & 10619 & 1286 & 3176 & 0.085 & 0.211 & 15081 \\
\hline Missing & 211 & 751 & 117 & 0.696 & 0.109 & 1079 \\
\hline \multicolumn{7}{|l|}{ Nationality } \\
\hline Foreigner & 15009 & 1342 & 2235 & 0.072 & 0.120 & 18585 \\
\hline
\end{tabular}


Characteristic

Employed Benefit Out of Benefit Out of Total recipient sample recipient sample

rate rate

\begin{tabular}{|c|c|c|c|c|c|c|}
\hline German & 166249 & 10391 & 24132 & 0.052 & 0.108 & 198072 \\
\hline Missing & 228 & 621 & 116 & 0.644 & 0.120 & 965 \\
\hline \multicolumn{7}{|l|}{ Sex } \\
\hline Female & 74477 & 4868 & 13064 & 0.053 & 0.141 & 9240 \\
\hline Male & 107009 & 7486 & 10718 & 0.060 & 0.086 & 125213 \\
\hline \multicolumn{7}{|l|}{ Children } \\
\hline 0 children & 144666 & 6877 & 20456 & 0.040 & 0.119 & 171998 \\
\hline 1 child & 15308 & 2968 & 1525 & 0.150 & 0.077 & 19801 \\
\hline 2 children & 10973 & 0 & 421 & 0.000 & 0.037 & 11394 \\
\hline 3 children & 3235 & 0 & 129 & 0.000 & 0.038 & 3364 \\
\hline 4 children & 886 & 0 & 39 & 0.000 & 0.042 & 925 \\
\hline 5 children & 298 & 0 & 15 & 0.000 & 0.047 & 313 \\
\hline 6 children & 103 & 0 & 7 & 0.000 & 0.061 & 110 \\
\hline 7 children & 36 & 0 & 2 & 0.000 & 0.048 & 37 \\
\hline$>7$ children & 375 & 0 & 8 & 0.000 & 0.021 & 383 \\
\hline Missing & 5607 & 2509 & 1182 & 0.270 & 0.127 & 9298 \\
\hline \multicolumn{7}{|l|}{ Wages $^{(h)}$} \\
\hline $0-50$ & 31390 & 2045 & 16506 & 0.041 & 0.331 & 49941 \\
\hline $51-100$ & 63992 & 5173 & 21942 & 0.057 & 0.241 & 91107 \\
\hline $101-150$ & 49653 & 2310 & 9244 & 0.038 & 0.151 & 61207 \\
\hline $151-200$ & 20712 & 690 & 1812 & 0.030 & 0.078 & 23241 \\
\hline $201-250$ & 7527 & 248 & 619 & 0.030 & 0.074 & 8394 \\
\hline 251-299 & 2057 & 38 & 51 & 0.018 & 0.024 & 2146 \\
\hline $300^{(i)}$ & 694 & 92 & 1600 & 0.039 & 0.671 & 2386 \\
\hline Missing & 19 & 724 & 81 & 0.879 & 0.098 & 824 \\
\hline \multicolumn{7}{|l|}{ Age } \\
\hline$<16$ years $^{(j)}$ & 5974 & 376 & 799 & 0.053 & 0.112 & 7149 \\
\hline $16-20$ years & 12379 & 562 & 843 & 0.041 & 0.061 & 13784 \\
\hline $21-25$ years & 21501 & 1830 & 3907 & 0.067 & 0.143 & 27238 \\
\hline 26-30 years & 22316 & 1752 & 4885 & 0.061 & 0.169 & 28952 \\
\hline $31-35$ years & 21101 & 1408 & 4190 & 0.053 & 0.157 & 26699 \\
\hline $36-40$ years & 21276 & 1151 & 3339 & 0.045 & 0.130 & 25765 \\
\hline $41-45$ years & 20745 & 1066 & 2331 & 0.044 & 0.097 & 24142 \\
\hline 46-50 years & 18906 & 1033 & 1432 & 0.048 & 0.067 & 21371 \\
\hline $51-55$ years & 16275 & 1184 & 896 & 0.064 & 0.049 & 18355 \\
\hline $56-60$ years & 10315 & 1597 & 560 & 0.128 & 0.045 & 12472 \\
\hline 61-62 years & 756 & 125 & 49 & 0.134 & 0.053 & 930 \\
\hline$>62$ years $(k)$ & 9944 & 271 & 551 & 0.025 & 0.671 & 10766 \\
\hline
\end{tabular}


${ }^{(a)}$ Working less than half of normal time

${ }^{(b)}$ Working more than half of normal time

${ }^{(c)}$ No vocational training degree, High School Diploma

${ }^{(d)}$ Vocational training degree, no High School Diploma

${ }^{(e)}$ No vocational training degree, High School Diploma

${ }^{(f)}$ Vocational training degree, High School Diploma

${ }^{(h)}$ In DM per day

${ }^{(i)}$ Top coding category for part of the employees

${ }^{(j)}$...when entering the labor market

${ }^{(k)}$...when leaving the labor market

Table 2: Transition rates for all employees (in \%)

\begin{tabular}{c|c|c|c|c} 
E-OE & E-SE & E-BR & E-OOS & E-LS \\
\hline 7.85 & 82.55 & 2.92 & 3.19 & 3.49
\end{tabular}

\begin{tabular}{c|c|c|c} 
BR-E & BR-BR & BR-OOS & BR-LS \\
\hline 25.87 & 42.62 & 15.13 & 16.38
\end{tabular}

\begin{tabular}{c|c|c|c} 
OOS-E & OOS-BR & OOS-OOS & OOS-LS \\
\hline 24.68 & 6.57 & 65.02 & 3.72
\end{tabular}

E: employed, OE: other employer than in the previous year, SE: same employer as in previous year, BR: benefit recipient, OOS: out of sample, LS: last spell (vanishes from the data set) 
Table 3: Transition rates across demographic groups

(in \%)

All employees

men

woman

Germans

foreigners

married

single

low skilled medium skilled high skilled

low wage

mid wage

high wage

A16-20

A21-25

A26-30

A31-35

A36-40

A41-45

A46-50
E-OE E-SE E-BR E-OOS E-LS BR-E BR-BR BR-OOS BR-LS OOS-E OOS-BR OOS-OOS OOS-LS

$\begin{array}{ccccccccccccc}7.85 & 82.55 & 2.92 & 3.19 & 3.49 & 25.87 & 42.62 & 15.13 & 16.38 & 24.68 & 6.57 & 65.02 & 3.72 \\ & & & & & & & & & & & & \\ 7.58 & 83.68 & 2.72 & 2.77 & 3.26 & 26.45 & 48.18 & 11.8 & 13.57 & 26.8 & 8.72 & 60.44 & 4.05 \\ 8.24 & 80.9 & 3.23 & 3.8 & 3.82 & 25.16 & 34.53 & 19.88 & 20.44 & 22.87 & 4.76 & 68.91 & 3.46 \\ & & & & & & & & & & & & \\ 7.83 & 82.97 & 2.83 & 3.13 & 3.24 & 25.73 & 41.97 & 15.22 & 17.07 & 24.49 & 6.37 & 65.9 & 3.25 \\ 7.47 & 78.31 & 3.88 & 4.2 & 6.14 & 23.31 & 42.42 & 15.61 & 18.66 & 26.68 & 7.48 & 58.63 & 7.22 \\ & & & & & & & & & & & & \\ 4.92 & 82.87 & 2.4 & 6.27 & 3.53 & 18.11 & 39.34 & 19.93 & 22.62 & 29.15 & 5.79 & 62.85 & 2.2 \\ 9 & 74.86 & 2.73 & 10.03 & 3.38 & 26.56 & 47.56 & 16.59 & 9.29 & 24.59 & 3.11 & 70.62 & 1.68 \\ & & & & & & & & & & & & \\ 4.70 & 82.09 & 3.62 & 5.35 & 4.24 & 13.16 & 48.89 & 17.61 & 20.34 & 21.07 & 6.02 & 70.10 & 2.81 \\ 6.70 & 84.24 & 2.48 & 3.62 & 2.97 & 23.31 & 39.78 & 18.66 & 18.24 & 25.02 & 5.27 & 67.47 & 2.23 \\ 7 & 83.37 & 1.69 & 3.01 & 4.93 & 22.97 & 37.37 & 16.75 & 22.9 & 27.59 & 3.85 & 65.72 & 2.84 \\ & & & & & & & & & & & & \\ 7.48 & 72.20 & 4.16 & 11.86 & 4.30 & 16.34 & 42.53 & 24.82 & 16.32 & 19.83 & 3.86 & 74.19 & 2.12 \\ 6.93 & 76.19 & 3.49 & 10.69 & 2.70 & 22.03 & 44.97 & 18.56 & 14.44 & 30.10 & 4.14 & 64.31 & 1.45 \\ 4.24 & 81.26 & 1.50 & 10.75 & 2.25 & 14.30 & 43.19 & 18.82 & 23.70 & 42.23 & 2.45 & 54.34 & 0.98 \\ & & & & & & & & & & & & \\ 11.94 & 76.5 & 4.63 & 3.92 & 3.01 & 24.33 & 46.99 & 10.26 & 18.42 & 44.6 & 10.57 & 37.61 & 7.22 \\ 14.24 & 71.5 & 5.17 & 5.49 & 3.6 & 32.06 & 42.67 & 12.3 & 12.96 & 38.91 & 13.66 & 41.53 & 5.9 \\ 10.17 & 78.45 & 4.38 & 3.21 & 3.79 & 29.4 & 43.9 & 10.9 & 15.8 & 36.38 & 15.76 & 40.07 & 7.79 \\ 8.32 & 82.71 & 3.37 & 2.28 & 3.31 & 27.91 & 46.82 & 11.04 & 14.22 & 36.71 & 16.32 & 39.9 & 7.07 \\ 6.99 & 86.25 & 2.67 & 1.59 & 2.49 & 25.57 & 51.44 & 9.82 & 13.18 & 36.36 & 17.94 & 37.59 & 8.11 \\ 5.95 & 88.19 & 2.44 & 1.25 & 2.17 & 23.11 & 53.31 & 8.86 & 14.72 & 34.77 & 20 & 36.16 & 9.07 \\ 4.97 & 89.11 & 2.42 & 1.13 & 2.37 & 18.46 & 56.74 & 7.71 & 17.09 & 31.62 & 24.33 & 31.75 & 12.3\end{array}$


(in \%)

A51-55

A56-60

A61-62

apprentices

clerks

craftsmen

simple workers

foremen

part-time

construction

farming; energy

services

food and stimulants

basic industry

commerce

durable goods

social insurance and

local authorities

consumption goods

traffic; telecommunication
E-OE E-SE E-BR E-OOS E-LS BR-E BR-BR BR-OOS BR-LS OOS-E OOS-BR OOS-OOS OOS-LS

$\begin{array}{ccccccccccccc}3.97 & 88.44 & 2.99 & 1.04 & 3.57 & 11.91 & 58.18 & 5.28 & 24.63 & 26.93 & 29.51 & 26.89 & 16.68 \\ 2.66 & 76.75 & 6.25 & 1.42 & 12.92 & 3.56 & 43.96 & 2.24 & 50.24 & 14.46 & 39.61 & 17.4 & 28.53 \\ 0.89 & 28.42 & 11.73 & 1.15 & 57.82 & 0.08 & 17.18 & 0.04 & 82.7 & 0 & 26.95 & 0 & 73.05 \\ & & & & & & & & & & & & \\ 5.79 & 81.2 & 3.1 & 7.19 & 2.71 & 12.33 & 44.73 & 23.14 & 19.8 & 26.67 & 4.19 & 67.59 & 1.56 \\ 7.18 & 84.22 & 2.13 & 3.23 & 3.23 & 22.08 & 37.6 & 18.18 & 22.14 & 24.33 & 4.22 & 69.4 & 2.05 \\ 5.53 & 84.38 & 3.03 & 4.16 & 2.89 & 18.78 & 49.67 & 15.58 & 15.97 & 25.53 & 7.05 & 65.24 & 2.18 \\ 5.03 & 81.58 & 4.28 & 4.76 & 4.35 & 15.12 & 50.29 & 16.42 & 18.18 & 20.8 & 7.68 & 68.06 & 3.46 \\ 3.23 & 88.57 & 1.93 & 2.47 & 3.8 & 10.09 & 43.34 & 8.78 & 37.79 & 29.94 & 5.96 & 61.07 & 3.03 \\ 3.69 & 83.26 & 2.58 & 5.17 & 5.29 & 11.68 & 35.06 & 22.67 & 30.59 & 20.47 & 2.74 & 74.18 & 2.61 \\ & & & & & & & & & & & & \\ 5.61 & 82.14 & 4.6 & 4.35 & 3.3 & 21.04 & 53.12 & 14.83 & 11.01 & 20.9 & 9.83 & 66.41 & 2.86 \\ 3.54 & 86.98 & 2.26 & 2.73 & 4.5 & 13.8 & 56.43 & 12.47 & 17.3 & 21.26 & 9.99 & 64.47 & 4.29 \\ 6.89 & 81.65 & 2.65 & 4.7 & 4.12 & 18.06 & 44.89 & 22.01 & 15.04 & 19.54 & 4.43 & 73.42 & 2.61 \\ 3.77 & 85.88 & 2.97 & 3.72 & 3.67 & 10 & 47.18 & 17.08 & 25.74 & 19.71 & 6.63 & 70.51 & 3.15 \\ 1.95 & 90.27 & 2.83 & 2.06 & 2.89 & 8.63 & 54.98 & 9.44 & 26.95 & 20.55 & 8.86 & 67.56 & 3.04 \\ 6.2 & 82.73 & 3.16 & 4.41 & 3.5 & 15.24 & 42.31 & 19.55 & 22.89 & 19.43 & 4.59 & 73.75 & 2.23 \\ 3.13 & 89.08 & 2.43 & 2.79 & 2.58 & 11.61 & 45.72 & 14.77 & 27.9 & 21.95 & 6.56 & 69.23 & 2.26 \\ 3.15 & 88.82 & 1.67 & 1.97 & 4.39 & 10.5 & 56.83 & 15.53 & 17.14 & 19.98 & 7.41 & 69 & 3.61 \\ & & & & & & & & & & & & \\ 3.35 & 86.75 & 3.51 & 2.89 & 3.5 & 12.24 & 44.52 & 14.72 & 28.53 & 20.81 & 7.83 & 68.28 & 3.09 \\ 6.56 & 83.59 & 2.05 & 3.4 & 4.39 & 14.65 & 50.12 & 18.69 & 16.54 & 20.94 & 6.18 & 69.58 & 3.3\end{array}$




\section{A.3 Development of stocks over time}

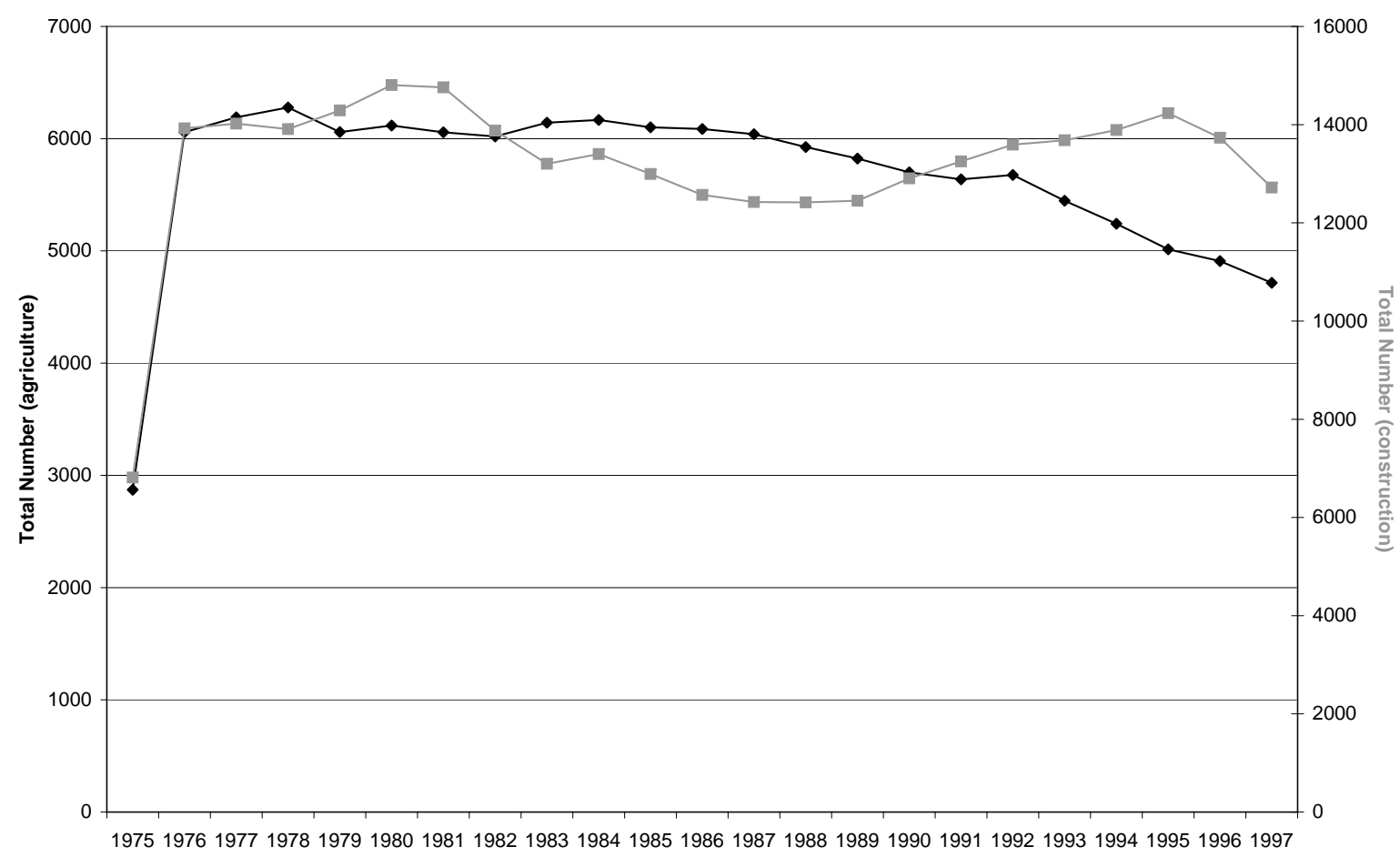

Figure 5: Development of employment in agriculture and construction

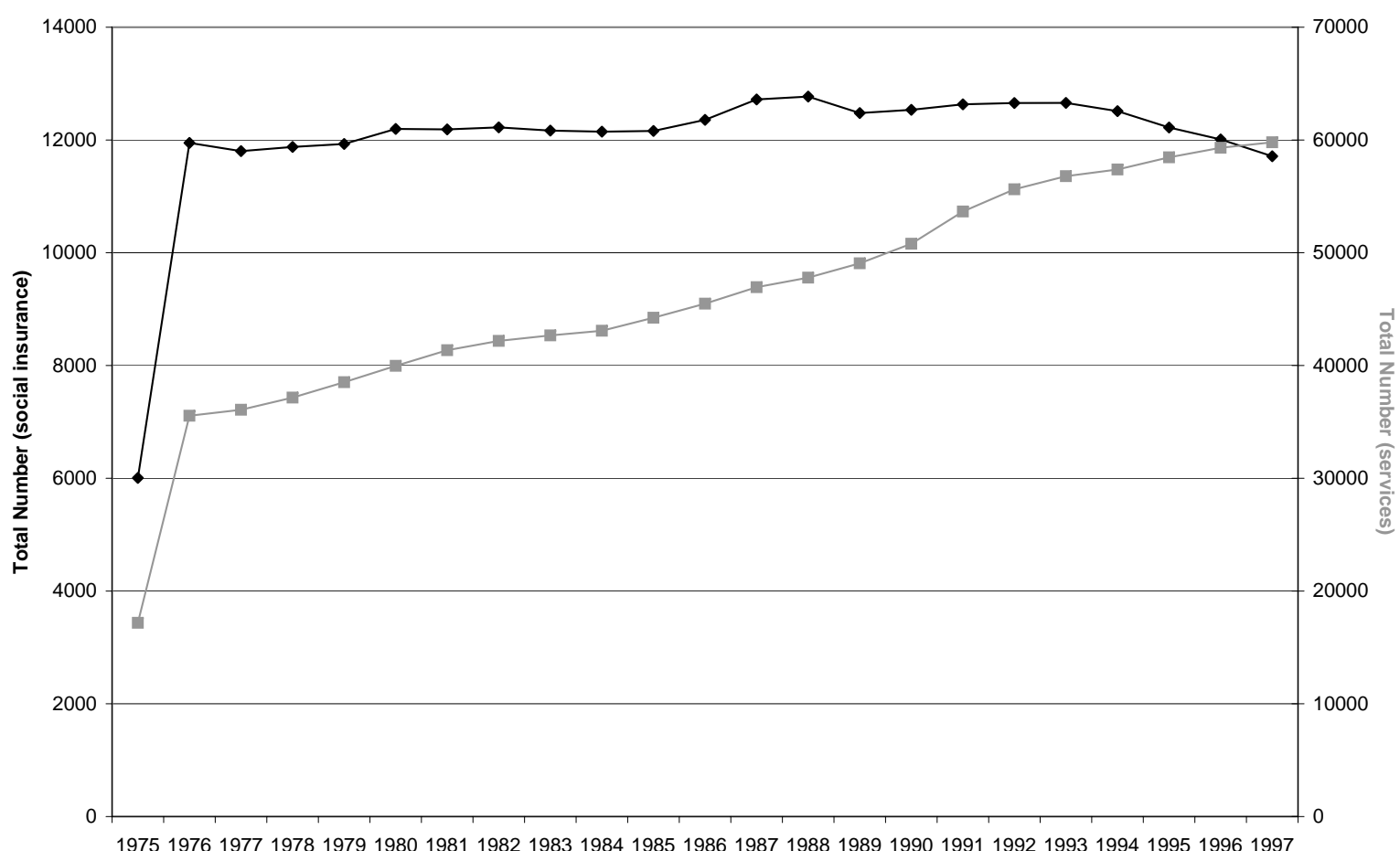

Figure 6: Development of employment in social insurance and services 


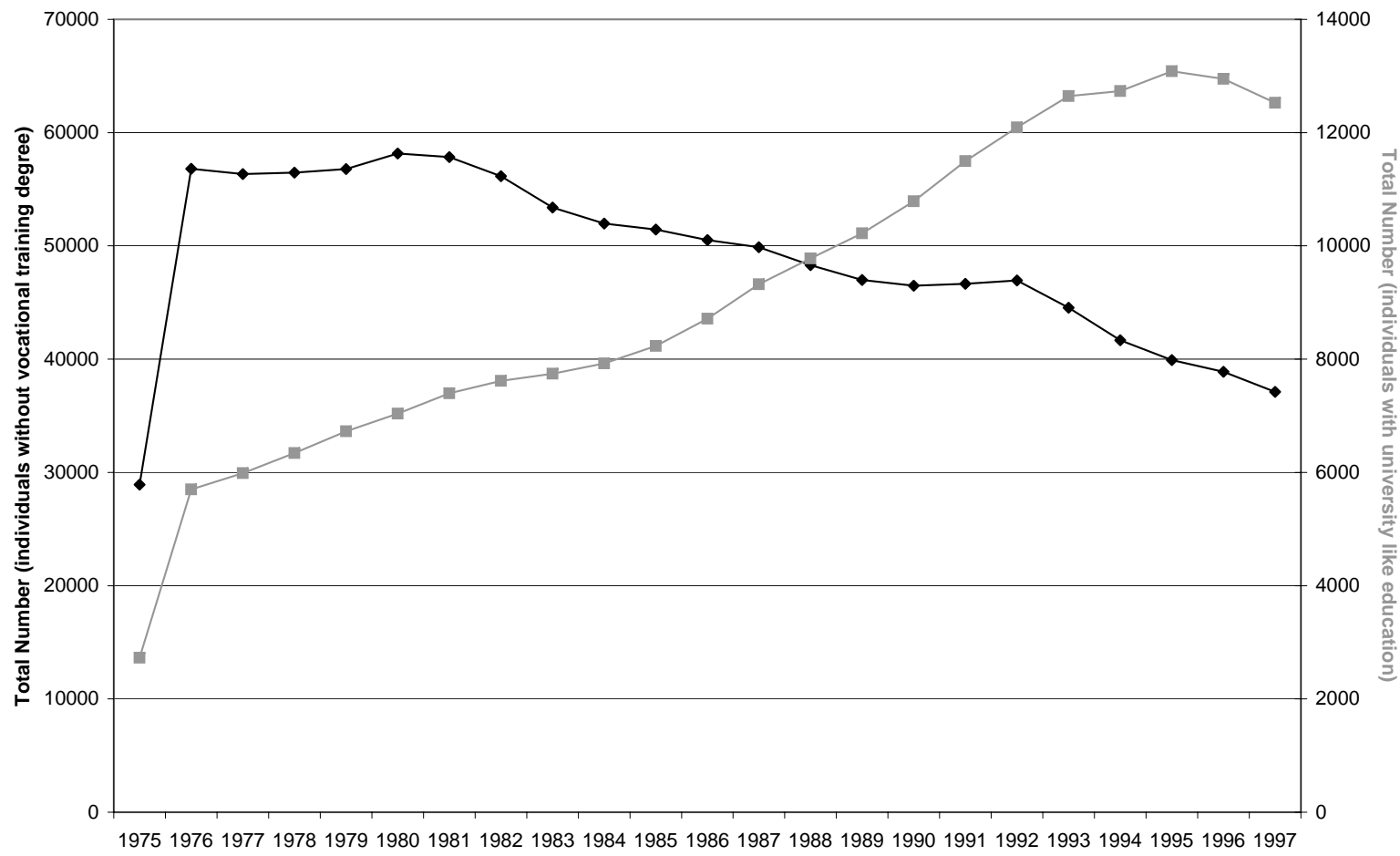

Figure 7: Total number of low-skilled and high-skilled employees over time

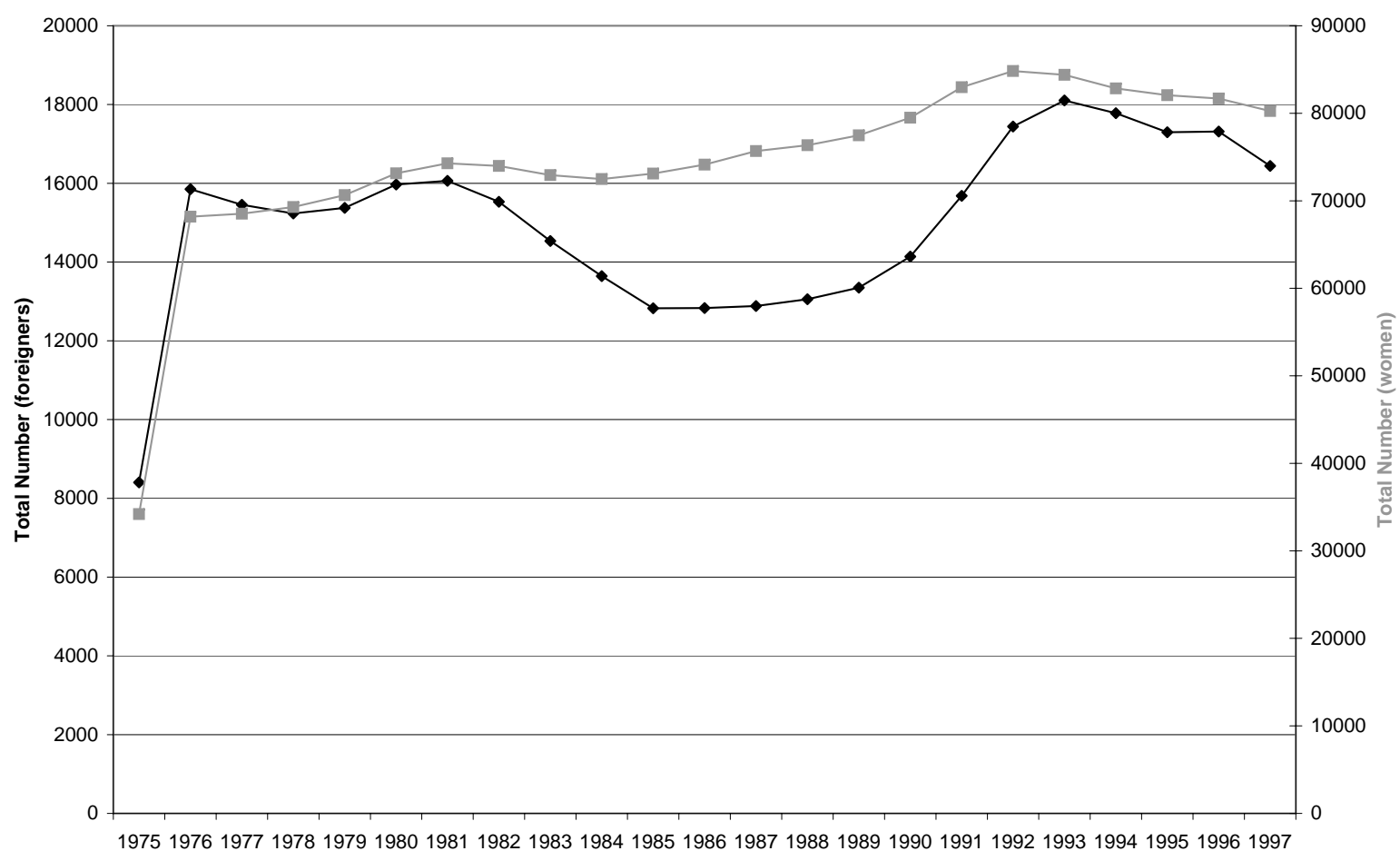

Figure 8: Total number of employed women and foreigners (individuals without German nationality) over time 
Table 4: Correlation of real GDP growth with transition rates

\begin{tabular}{l|c|c}
$\begin{array}{l}\text { Correlation between } \\
\text { transition rate from ... }\end{array}$ & $\begin{array}{c}\ldots \text { and real GDP growth } \\
\text { (correlation coefficient) }\end{array}$ & Standard deviation \\
\hline job to other job & 0.450 & 0.200 \\
\hline job to other job $(\mathrm{t}+1)$ & 0.508 & 0.198 \\
\hline job to same job & 0.205 & 0.219 \\
\hline job to BR & -0.381 & 0.207 \\
\hline job to BR $(\mathrm{t}+1)$ & -0.527 & 0.195 \\
\hline BR to employment & 0.135 & 0.227 \\
\hline BR to employment $(\mathrm{t}+1)$ & 0.542 & 0.193 \\
\hline BR to other states & 0.177 & 0.226 \\
\hline job to not same job & -0.205 & 0.219 \\
\hline
\end{tabular}

BR: Benefit recipiency state as defined in the data section. 


\section{A.4 Wage distributions for different groups and years}

Log-wage distribution for:

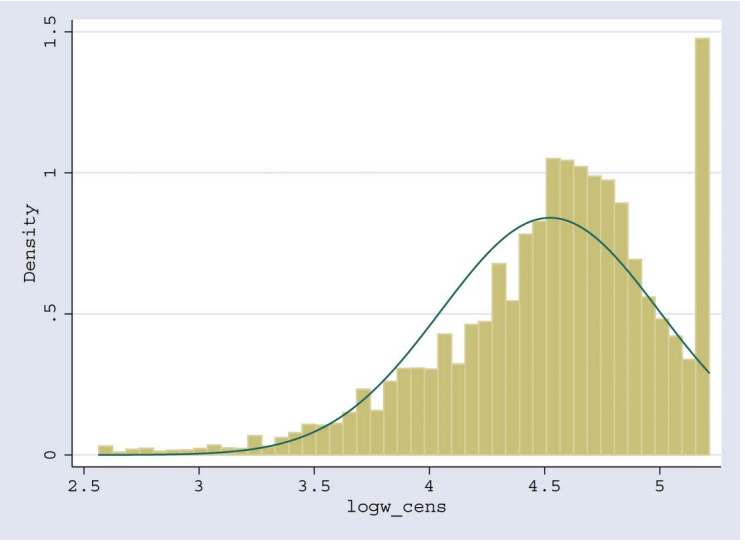

Figure 9: full-time employed individuals (including apprentices) in 1986

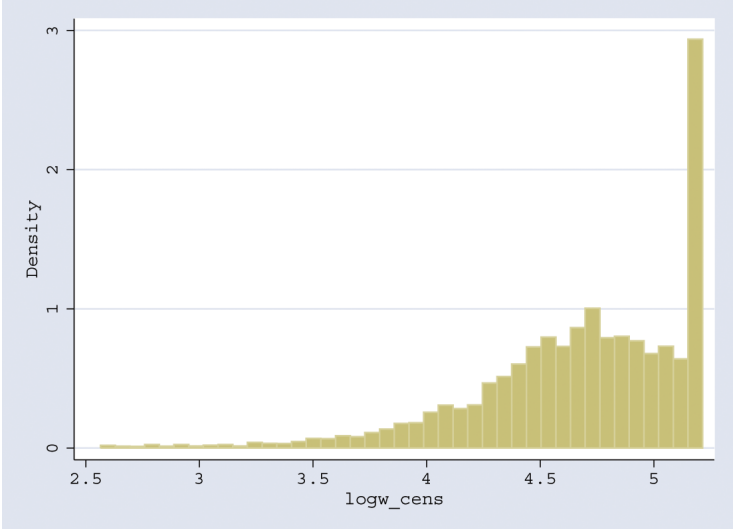

Figure 11: clerks in 1986

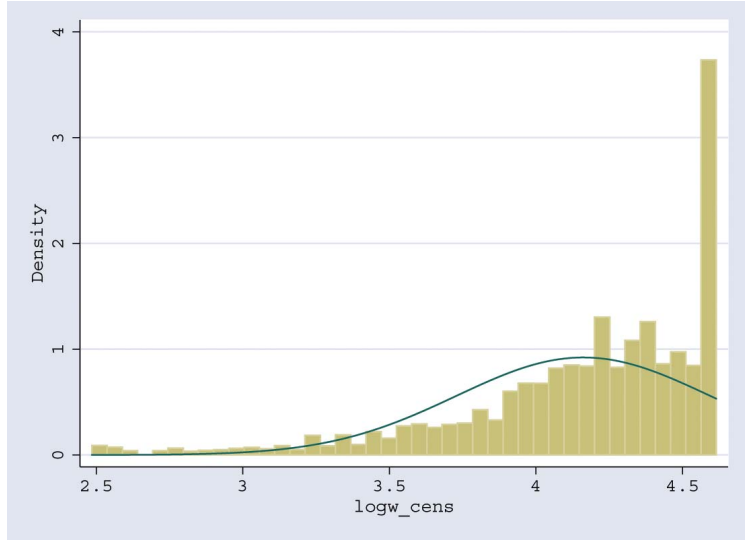

Figure 10: clerks in 1976

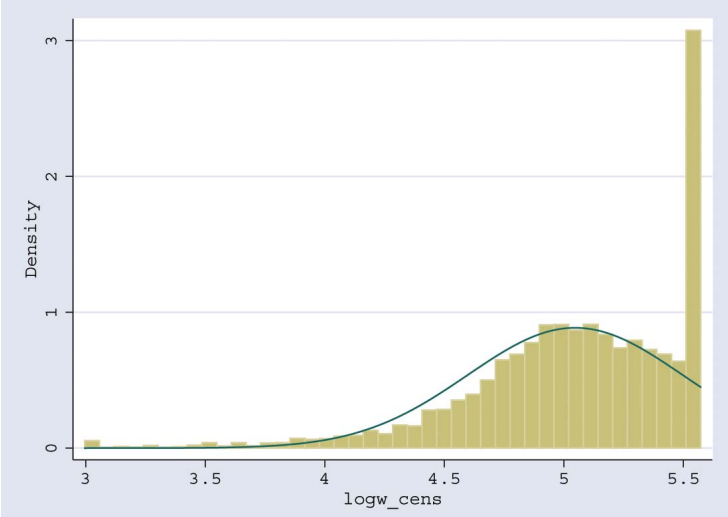

Figure 12: clerks in 1996 


\section{A.5 Results from direct job-to-job changes for different wage definitions}

For the first wage definition (A) we performed separate Tobit-regressions for the censoring above and below. For full-time employees (excluding apprentices, home workers and the missing category) we used Tobit-regressions to predict the conditional expectation for (deflated) wages that were censored from above within the group of full-time employed for each year. Other censored values were omitted from our analysis. We performed Tobit-regressions for part-time employees and apprentices to predict values that were censored from below and replaced the censored values with their conditional expectations. For the second definition (B) we did the same, but we used data from the official statistics for the mean of the wage distribution to predict conditional expectations. For the third definition (C) we replaced all censored values by the censoring thresholds. Finally, for the fourth definition (D) we excluded all censored values from the analysis.

Table 5: Wage changes after job-to-job transitions for different wage definitions

\begin{tabular}{c|c|c|c|c} 
& Observations & Share winners & Share losers & No change \\
\hline Wage A & 274255 & 65.59 & 27.20 & 7.21 \\
Wage B & 274255 & 65.59 & 27.20 & 7.21 \\
Wage C & 274965 & 66.30 & 28.64 & 5.05 \\
Wage D & 252865 & 68.31 & 28.66 & 3.03
\end{tabular}

\begin{tabular}{c|c|c|c} 
& $\begin{array}{l}\text { Relative gain of } \\
\text { the winners (in \%) }\end{array}$ & $\begin{array}{l}\text { Relative loss of } \\
\text { the losers (in \%) }\end{array}$ & $\begin{array}{l}\text { Average wage } \\
\text { change (in \%) }\end{array}$ \\
\hline Wage A & 26.60 & -15.13 & 13.33 \\
Wage B & 26.64 & -15.15 & 13.35 \\
Wage C & 25.39 & -13.92 & 12.85 \\
Wage D & 24.88 & -14.28 & 12.90
\end{tabular}

There are some more observations in the $\mathrm{C}$ variable since, for wage $\mathrm{C}$, we do not omit full-time employed individuals, whose wage is censored from below. No change means that the wage is exactly the same before and after the job-to-job transition. Wage A: Tobit estimates for upper and lower bound. Wage B: Tobit estimates, based on the annual income data of the official statistics. Wage C: Censored values are replaced by their censoring threshold. Wage D: Censored values are excluded from our analysis.

As one can see in table 5, results do not differ by much. The maximum difference in the share of winners is less than 1 percentage point, while in the share of losers it is a bit more than 1 percentage point. The average gain differs by a maximum of 4 percentage points, while average losses differ by less than 2 percentage points. 
Table 7: Transitions within categories

\begin{tabular}{c|c|c|c|c} 
& Total & Share winners & Share losers & No change \\
\hline Full-time 2 to full-time 2 & 274255 & 0.656 & 0.272 & 0.072 \\
Part-time 1 to part-time 1 & 13375 & 0.643 & 0.291 & 0.066 \\
Part-time 2 to part-time 2 & 2217 & 0.549 & 0.289 & 0.162
\end{tabular}

\begin{tabular}{c|c|c|c} 
& $\begin{array}{c}\text { Relative gain } \\
\text { of the winners }\end{array}$ & $\begin{array}{c}\text { Relative loss } \\
\text { of the losers }\end{array}$ & $\begin{array}{c}\text { Overall } \\
\text { wage change }\end{array}$ \\
\hline Full-time 2 to full-time 2 & 0.266 & -0.151 & 0.133 \\
Part-time 1 to part-time 1 & 0.205 & -0.143 & 0.09 \\
Part-time 2 to part-time 2 & 0.268 & -0.162 & 0.101
\end{tabular}

Full-time 2: Within the group of full-time employed, excluding apprentices.

Part-time 1: Working hours are more than $50 \%$ of regular working hours.

Part-time 2: Working hours are less than or equal to $50 \%$ of regular working hours.

Table 8: Transitions within wage categories

\begin{tabular}{l|c|c|c|c} 
& Total & Share winners & Share losers & No change \\
\hline Tercile 1 & 101461 & 0.753 & 0.214 & 0.033 \\
Tercile 2 & 70786 & 0.681 & 0.293 & 0.025 \\
Tercile 3 & 61514 & 0.473 & 0.342 & 0.22
\end{tabular}

\begin{tabular}{l|c|c|c} 
& $\begin{array}{c}\text { Relative gain } \\
\text { of the winners }\end{array}$ & $\begin{array}{c}\text { Relative loss } \\
\text { of the losers }\end{array}$ & $\begin{array}{c}\text { Overall } \\
\text { wage change }\end{array}$ \\
\hline Tercile 1 & 0.391 & -0.156 & 0.247 \\
Tercile 2 & 0.176 & -0.155 & 0.063 \\
Tercile 3 & 0.172 & -0.215 & -0.012
\end{tabular}

Table 6: Transitions full-time to...

\begin{tabular}{c|c|c|c|c} 
& Observations & $\begin{array}{c}\text { Share } \\
\text { winners }\end{array}$ & $\begin{array}{c}\text { Share } \\
\text { losers }\end{array}$ & No change \\
\hline Full-time & 322636 & 0.646 & 0.281 & 0.073 \\
Part-time $(>50 \%$ regular time $)$ & 7820 & 0.444 & 0.532 & 0.025 \\
Part-time $(\leq 50 \%$ regular time $)$ & 1055 & 0.245 & 0.709 & 0.045
\end{tabular}

\begin{tabular}{c|c|c|c} 
& $\begin{array}{c}\text { Relative gain } \\
\text { of the winners }\end{array}$ & $\begin{array}{c}\text { Relative loss } \\
\text { of the losers }\end{array}$ & $\begin{array}{c}\text { Overall } \\
\text { wage change }\end{array}$ \\
\hline Full-time & 0.396 & -0.173 & 0.207 \\
Part-time (>50\% regular time) & 0.504 & -0.275 & 0.077 \\
Part-time ( $\leq 50 \%$ regular time) & 0.476 & -0.478 & -0.222
\end{tabular}


Table 9: Transitions within unemployed categories

\begin{tabular}{c|c|c|c|c} 
& Total & Share winners & Share losers & No change \\
\hline Unemployed $>3$ months & 48381 & 0.525 & 0.439 & 0.036 \\
Unemployed $>3 \leq 6$ months & 30251 & 0.509 & 0.448 & 0.043 \\
Unemployed $>6 \leq 9$ months & 13440 & 0.474 & 0.501 & 0.025 \\
Unemployed $>9 \leq 12$ months & 10815 & 0.449 & 0.532 & 0.019 \\
Unemployed $>12$ months & 43146 & 0.462 & 0.524 & 0.015 \\
\multicolumn{5}{|l|}{} \\
Unemployed $>3$ months & Relative gain & Relative loss & Overall \\
Unemployed $>3 \leq 6$ months & 0.277 & -0.179 & 0.103 \\
Unemployed $>6 \leq 9$ months & 0.392 & -0.196 & 0.096 & \\
Unemployed $>9 \leq 12$ months & 0.459 & -0.232 & 0.095 & \\
Unemployed $>12$ months & 0.533 & -0.268 & 0.083 & 0.109
\end{tabular}


Table 10: Share of winners and losers after job-to-job transitions by category

\begin{tabular}{|c|c|c|}
\hline Variable & Winners & Losers \\
\hline Vocational training degree & $\begin{array}{c}-0.031^{* * *} \\
(0.009)\end{array}$ & $\begin{array}{c}-0.013^{* *} \\
(0.006)\end{array}$ \\
\hline University/technical college & $\begin{array}{c}-0.179^{* * *} \\
(0.009)\end{array}$ & $\begin{array}{c}-0.17^{* * *} \\
(0.006)\end{array}$ \\
\hline 28-30 years & $\begin{array}{l}-0.025 \\
(0.016)\end{array}$ & $\begin{array}{l}-0.013 \\
(0.011)\end{array}$ \\
\hline 31-33 years & $\begin{array}{c}-0.079^{* * *} \\
(0.016)\end{array}$ & $\begin{array}{c}-0.01 \\
(0.011)\end{array}$ \\
\hline $34-36$ years & $\begin{array}{c}-0.117^{* * *} \\
(0.016)\end{array}$ & $\begin{array}{c}-0.035^{* * *} \\
(0.011)\end{array}$ \\
\hline 37-39 years & $\begin{array}{c}-0.155^{* * *} \\
(0.017)\end{array}$ & $\begin{array}{c}-0.04^{* * *} \\
(0.011)\end{array}$ \\
\hline 40-42 years & $\begin{array}{c}-0.141^{* * *} \\
(0.017)\end{array}$ & $\begin{array}{c}-0.06^{* * *} \\
(0.011)\end{array}$ \\
\hline $43-45$ years & $\begin{array}{c}-0.168^{* * *} \\
(0.017)\end{array}$ & $\begin{array}{c}-0.042^{* * *} \\
(0.011)\end{array}$ \\
\hline $46-48$ years & $\begin{array}{c}-0.154^{* * *} \\
(0.017)\end{array}$ & $\begin{array}{c}-0.055^{* * *} \\
(0.012)\end{array}$ \\
\hline $49-51$ years & $\begin{array}{c}-0.156^{* * *} \\
(0.017)\end{array}$ & $\begin{array}{c}-0.056^{* * *} \\
(0.012)\end{array}$ \\
\hline $52-54$ years & $\begin{array}{c}-0.177^{* * *} \\
(0.017)\end{array}$ & $\begin{array}{c}-0.046^{* * *} \\
(0.012)\end{array}$ \\
\hline Time & $\begin{array}{c}0.1 \mathrm{E}-02 \\
(0.1 \mathrm{E}-02)\end{array}$ & $\begin{array}{c}0.1 \mathrm{E}-02^{* * *} \\
(0)\end{array}$ \\
\hline Relative gain/loss & $\begin{array}{c}-0.197^{* * *} \\
(0.055)\end{array}$ & $\begin{array}{c}0.02 \\
(0.037)\end{array}$ \\
\hline Intercept & $\begin{array}{l}-0.781 \\
(1.103) \\
\end{array}$ & $\begin{array}{c}-2.506^{* * *} \\
(0.747) \\
\end{array}$ \\
\hline $\mathrm{N}$ & 687 & 687 \\
\hline $\mathrm{R}^{2}$ & 0.518 & 0.607 \\
\hline$\chi_{(13)}^{2}$ & 723.66 & 1037.57 \\
\hline Significance levels: & $* *: 5 \%$ & $* * *: 1 \%$ \\
\hline
\end{tabular}


Table 11: Relative gain or loss after job-to-job transitions by category

\begin{tabular}{|c|c|c|}
\hline Variable & Winners & Losers \\
\hline Vocational training degree & $\begin{array}{l}-0.004 \\
(0.006)\end{array}$ & $\begin{array}{c}0.001 \\
(0.005)\end{array}$ \\
\hline University/technical college & $\begin{array}{c}0.025^{* * *} \\
(0.008)\end{array}$ & $\begin{array}{c}-0.016^{* *} \\
(0.007)\end{array}$ \\
\hline 28-30 years & $\begin{array}{c}-0.025^{* *} \\
(0.011)\end{array}$ & $\begin{array}{l}-0.003 \\
(0.009)\end{array}$ \\
\hline 31-33 years & $\begin{array}{c}-0.04^{* * *} \\
(0.012)\end{array}$ & $\begin{array}{c}0 \\
(0.009)\end{array}$ \\
\hline 34-36 years & $\begin{array}{c}-0.049^{* * *} \\
(0.012)\end{array}$ & $\begin{array}{c}0.003 \\
(0.009)\end{array}$ \\
\hline 37-39 years & $\begin{array}{c}-0.088^{* * *} \\
(0.012)\end{array}$ & $\begin{array}{c}0.004 \\
(0.009)\end{array}$ \\
\hline 40-42 years & $\begin{array}{c}-0.092^{* * *} \\
(0.012)\end{array}$ & $\begin{array}{l}-0.002 \\
(0.009)\end{array}$ \\
\hline $43-45$ years & $\begin{array}{c}-0.085^{* * *} \\
(0.012)\end{array}$ & $\begin{array}{c}0.002 \\
(0.009)\end{array}$ \\
\hline 46-48 years & $\begin{array}{c}-0.108^{* * *} \\
(0.012)\end{array}$ & $\begin{array}{c}0.01 \\
(0.009)\end{array}$ \\
\hline 49-51 years & $\begin{array}{c}-0.118^{* * *} \\
(0.012)\end{array}$ & $\begin{array}{c}0.013 \\
(0.009)\end{array}$ \\
\hline $52-54$ years & $\begin{array}{c}-0.121^{* * *} \\
(0.012)\end{array}$ & $\begin{array}{c}0.01 \\
(0.009)\end{array}$ \\
\hline Time & $\begin{array}{c}-0.1 \mathrm{E}-02 \\
(0)\end{array}$ & $\begin{array}{c}0.2 \mathrm{E}-02^{* * *} \\
(0)\end{array}$ \\
\hline Share of winners/losers & $\begin{array}{c}-0.095^{* * *} \\
(0.027)\end{array}$ & $\begin{array}{l}0.01^{* * *} \\
(0.032)\end{array}$ \\
\hline Intercept & $\begin{array}{c}1.366^{*} \\
(0.764) \\
\end{array}$ & $\begin{array}{c}-3.235^{* * *} \\
(0.591) \\
\end{array}$ \\
\hline $\mathrm{N}$ & 687 & 665 \\
\hline $\mathrm{R}^{2}$ & 0.286 & 0.135 \\
\hline$\chi_{(13)}^{2}$ & 275.18 & 103.79 \\
\hline
\end{tabular}


Table 12: Wage growth for job changers and stayers

$1975 \quad 1976 \quad 1977 \quad 1978$

stayers changers stayers changers stayers changers stayers changers

\begin{tabular}{rcccccccc}
\hline year & 0.046 & 0.183 & 0.059 & 0.231 & 0.051 & 0.127 & 0.048 & 0.096 \\
year+1 & 0.055 & 0.066 & 0.046 & 0.056 & 0.043 & 0.039 & 0.033 & 0.031 \\
year+2 & 0.041 & 0.043 & 0.035 & 0.037 & 0.024 & 0.030 & 0.002 & -0.001 \\
year+3 & 0.033 & 0.033 & 0.019 & 0.027 & -0.006 & -0.004 & -0.005 & -0.005 \\
year+4 & 0.015 & 0.025 & -0.007 & -0.008 & -0.007 & -0.009 & 0.004 & 0.012
\end{tabular}

1979

1980

1981

1982

stayers changers stayers changers stayers changers stayers changers

\begin{tabular}{rllllllll}
\hline year & 0.040 & 0.081 & 0.017 & 0.057 & 0.022 & 0.037 & 0.036 & 0.047 \\
year+1 & 0.013 & 0.007 & 0.019 & 0.005 & 0.031 & 0.024 & 0.062 & 0.043 \\
year+2 & 0.006 & 0.000 & 0.019 & 0.018 & 0.048 & 0.042 & 0.033 & 0.027 \\
year+3 & 0.007 & 0.014 & 0.037 & 0.037 & 0.022 & 0.024 & 0.047 & 0.046 \\
year+4 & 0.034 & 0.035 & 0.021 & 0.022 & 0.046 & 0.047 & 0.031 & 0.034
\end{tabular}

$1983 \quad 1984 \quad 1985 \quad 1986$

stayers changers stayers changers stayers changers stayers changers

\begin{tabular}{rrrrrrrrr}
\hline year & 0.065 & 0.066 & 0.051 & 0.054 & 0.083 & 0.070 & 0.071 & 0.067 \\
year+1 & 0.046 & 0.028 & 0.078 & 0.051 & 0.066 & 0.044 & 0.058 & 0.039 \\
year+2 & 0.062 & 0.047 & 0.048 & 0.039 & 0.045 & 0.030 & 0.024 & 0.016 \\
year+3 & 0.034 & 0.035 & 0.029 & 0.028 & 0.010 & 0.008 & 0.036 & 0.037 \\
year+4 & 0.027 & 0.026 & 0.009 & 0.010 & 0.032 & 0.035 & 0.027 & 0.032
\end{tabular}

$1987 \quad 1988 \quad 1989 \quad 1990$

stayers changers stayers changers stayers changers stayers changers

\begin{tabular}{rllllllll}
\hline year & 0.062 & 0.073 & 0.051 & 0.051 & 0.086 & 0.077 & 0.077 & 0.070 \\
year+1 & 0.046 & 0.019 & 0.074 & 0.044 & 0.069 & 0.037 & 0.042 & 0.024 \\
year+2 & 0.051 & 0.040 & 0.048 & 0.033 & 0.039 & 0.022 & 0.036 & 0.014 \\
year+3 & 0.029 & 0.030 & 0.024 & 0.018 & 0.014 & 0.008 & 0.009 & 0.008 \\
year+4 & 0.018 & 0.017 & 0.005 & 0.006 & 0.002 & 0.003 & 0.029 & 0.028
\end{tabular}

1991

1992

stayers changers stayers changers

\begin{tabular}{rrrrr}
\hline year & 0.049 & 0.060 & 0.042 & 0.049 \\
year +1 & 0.039 & 0.017 & 0.036 & 0.015 \\
year+2 & 0.027 & 0.012 & 0.058 & 0.031 \\
year+3 & 0.037 & 0.029 & 0.012 & 0.010 \\
year+4 & 0.004 & 0.007 & 0.004 & 0.002
\end{tabular}


Table 13: Share of winners and losers after job-to-job transitions by category, controlling for the position in the wage distribution

\begin{tabular}{|c|c|c|}
\hline Variable & "Winners & Losers \\
\hline Tercile 2 & $\begin{array}{c}-0.038^{* * *} \\
(0.009)\end{array}$ & $\begin{array}{c}0.084^{* * *} \\
(0.008)\end{array}$ \\
\hline Tercile 3 & $\begin{array}{c}-0.274^{* * *} \\
(0.009)\end{array}$ & $\begin{array}{c}0.140^{* * *} \\
(0.008)\end{array}$ \\
\hline Medium-skilled & $\begin{array}{c}0.010 \\
(0.007)\end{array}$ & $\begin{array}{r}-0.059^{* * *} \\
(0.007)\end{array}$ \\
\hline High-skilled & $\begin{array}{c}0.069^{* * *} \\
(0.009)\end{array}$ & $\begin{array}{c}-0.111^{* * *} \\
(0.009)\end{array}$ \\
\hline 28-30 years & $\begin{array}{c}0.071^{* * *} \\
(0.015)\end{array}$ & $\begin{array}{c}-0.080^{* * *} \\
(0.015)\end{array}$ \\
\hline 31-33 years & $\begin{array}{c}0.069^{* * *} \\
(0.015)\end{array}$ & $\begin{array}{r}-0.112^{* * *} \\
(0.016)\end{array}$ \\
\hline $34-36$ years & $\begin{array}{l}0.036^{* *} \\
(0.015)\end{array}$ & $\begin{array}{c}-0.133^{* * *} \\
(0.016)\end{array}$ \\
\hline 37-39 years & $\begin{array}{l}0.034^{* *} \\
(0.015)\end{array}$ & $\begin{array}{c}-0.146^{* * *} \\
(0.016)\end{array}$ \\
\hline $40-42$ years & $\begin{array}{c}0.055^{* * *} \\
(0.015)\end{array}$ & $\begin{array}{c}-0.133^{* * *} \\
(0.016)\end{array}$ \\
\hline $43-45$ years & $\begin{array}{c}0.081^{* * *} \\
(0.015)\end{array}$ & $\begin{array}{c}-0.125^{* * *} \\
(0.017)\end{array}$ \\
\hline $46-48$ years & $\begin{array}{c}0.088^{* * *} \\
(0.016)\end{array}$ & $\begin{array}{c}-0.137^{* * *} \\
(0.017)\end{array}$ \\
\hline 49-51 years & $\begin{array}{c}0.118^{* * *} \\
(0.016)\end{array}$ & $\begin{array}{r}-0.161^{* * *} \\
(0.018)\end{array}$ \\
\hline $52-54$ years & $\begin{array}{c}0.234^{* * *} \\
(0.019)\end{array}$ & $\begin{array}{c}0.169^{* * *} \\
(0.023)\end{array}$ \\
\hline Relative gain/loss & $\begin{array}{c}0.117^{* * *} \\
(0.021)\end{array}$ & $\begin{array}{l}-0.023 \\
(0.050)\end{array}$ \\
\hline Intercept & $\begin{array}{c}0.628^{* * *} \\
(0.017)\end{array}$ & $\begin{array}{c}0.390^{* * *} \\
(0.020)\end{array}$ \\
\hline $\mathrm{N}$ & 1575 & 1575 \\
\hline $\mathrm{R}^{2}$ & 0.664 & 0.652 \\
\hline$\chi_{(14)}^{2}$ & 3112.5 & 2950.862 \\
\hline
\end{tabular}


Table 14: Relative gain or loss after job-to-job transitions by category, controlling for the position in the wage distribution

\begin{tabular}{|c|c|c|}
\hline Variable & Winners & Losers \\
\hline Tercile 2 & $\begin{array}{c}-0.207^{* * *} \\
(0.009)\end{array}$ & $\begin{array}{c}0.003 \\
(0.004)\end{array}$ \\
\hline Tercile 3 & $\begin{array}{c}-0.173^{* * *} \\
(0.012)\end{array}$ & $\begin{array}{r}-0.059^{* * *} \\
(0.004)\end{array}$ \\
\hline Medium-skilled & $\begin{array}{c}0.007 \\
(0.008)\end{array}$ & $\begin{array}{c}0.015^{\text {*** }} \\
(0.004)\end{array}$ \\
\hline High-skilled & $\begin{array}{c}0.102^{* * *} \\
(0.010)\end{array}$ & $\begin{array}{l}0.009^{*} \\
(0.005)\end{array}$ \\
\hline 28-30 years & $\begin{array}{c}-0.183^{* * *} \\
(0.016)\end{array}$ & $\begin{array}{c}0.140^{* * *} \\
(0.007)\end{array}$ \\
\hline 31-33 years & $\begin{array}{c}-0.210^{* * *} \\
(0.016)\end{array}$ & $\begin{array}{c}0.170^{* * *} \\
(0.007)\end{array}$ \\
\hline 34-36 years & $\begin{array}{c}-0.213^{* * *} \\
(0.016)\end{array}$ & $\begin{array}{c}0.174^{* * *} \\
(0.007)\end{array}$ \\
\hline 37-39 years & $\begin{array}{c}-0.218^{* * *} \\
(0.016)\end{array}$ & $\begin{array}{c}0.173^{* * *} \\
(0.007)\end{array}$ \\
\hline 40-42 years & $\begin{array}{c}-0.231^{* * *} \\
(0.017)\end{array}$ & $\begin{array}{c}0.170^{* * *} \\
(0.007)\end{array}$ \\
\hline $43-45$ years & $\begin{array}{c}-0.236^{* * *} \\
(0.017)\end{array}$ & $\begin{array}{c}0.174^{* * *} \\
(0.007)\end{array}$ \\
\hline $46-48$ years & $\begin{array}{c}-0.260^{* * *} \\
(0.017)\end{array}$ & $\begin{array}{c}0.185^{* * *} \\
(0.008)\end{array}$ \\
\hline 49-51 years & $\begin{array}{c}-0.287^{* * *} \\
(0.018)\end{array}$ & $\begin{array}{c}0.189^{* * *} \\
(0.008)\end{array}$ \\
\hline $52-54$ years & $\begin{array}{c}-0.303^{* * *} \\
(0.021)\end{array}$ & $\begin{array}{c}0.194^{* * *} \\
(0.010)\end{array}$ \\
\hline sharerwinners/losers & $\begin{array}{c}0.153^{* * *} \\
(0.027)\end{array}$ & $\begin{array}{l}-0.006 \\
(0.013)\end{array}$ \\
\hline Intercept & $\begin{array}{c}0.457^{* * *} \\
(0.024)\end{array}$ & $\begin{array}{r}-0.319^{* * *} \\
(0.008)\end{array}$ \\
\hline $\mathrm{N}$ & 1741 & 1608 \\
\hline $\mathrm{R}^{2}$ & 0.436 & 0.474 \\
\hline$\chi_{(14)}^{2}$ & 134.879 & 1449.034 \\
\hline
\end{tabular}




\section{A.6 Decile Transitions}

Table 15: Decile transitions

\begin{tabular}{|c|c|c|}
\hline Variable & Coefficient & (Std. err.) \\
\hline $28-30$ years & $-0.131^{* * *}$ & $(0.042)$ \\
\hline 31-33 years & $-0.199^{* * *}$ & $(0.046)$ \\
\hline $34-36$ years & $-0.255^{* * *}$ & $(0.049)$ \\
\hline $37-39$ years & $-0.299^{* * *}$ & $(0.053)$ \\
\hline 40-42 years & $-0.377^{* * *}$ & $(0.057)$ \\
\hline $43-45$ years & $-0.406^{* * *}$ & $(0.058)$ \\
\hline 46-48 years & $-0.437^{* * *}$ & $(0.061)$ \\
\hline 49-51 years & $-0.459^{* * *}$ & $(0.065)$ \\
\hline $52-54$ years & $-0.506^{* * *}$ & $(0.072)$ \\
\hline 1976 & $-0.153^{* * *}$ & $(0.058)$ \\
\hline 1977 & $-0.163^{* * *}$ & $(0.053)$ \\
\hline 1978 & $-0.151^{* * *}$ & $(0.051)$ \\
\hline 1979 & $-0.17^{* * *}$ & $(0.064)$ \\
\hline 1980 & $-0.225^{* * *}$ & $(0.053)$ \\
\hline 1981 & $-0.182^{* *}$ & $(0.075)$ \\
\hline 1982 & $-0.152^{* * *}$ & $(0.044)$ \\
\hline 1983 & $-0.253^{* * *}$ & $(0.080)$ \\
\hline 1984 & $-0.144^{* * *}$ & $(0.053)$ \\
\hline 1985 & -0.078 & $(0.063)$ \\
\hline 1986 & $-0.164^{* *}$ & $(0.069)$ \\
\hline 1987 & -0.034 & $(0.061)$ \\
\hline 1988 & -0.102 & $(0.062)$ \\
\hline 1989 & $-0.116^{*}$ & $(0.069)$ \\
\hline 1990 & $-0.226^{* * *}$ & $(0.083)$ \\
\hline 1991 & -0.047 & $(0.094)$ \\
\hline 1992 & -0.053 & $(0.067)$ \\
\hline 1993 & -0.082 & $(0.090)$ \\
\hline 1994 & -0.054 & $(0.074)$ \\
\hline 1995 & -0.041 & $(0.083)$ \\
\hline 1996 & -0.113 & $(0.083)$ \\
\hline Medium-skilled & $0.242^{* * *}$ & $(0.041)$ \\
\hline High-skilled & $0.273^{* * *}$ & $(0.044)$ \\
\hline Job change dummy & $0.285^{* * *}$ & $(0.008)$ \\
\hline Interquantile Range & $-9.34 \mathrm{E}-04$ & $(1.23 \mathrm{E}-03)$ \\
\hline E-E & $5.37 \mathrm{E}-05^{* *}$ & $(2.26 \mathrm{E}-05)$ \\
\hline $\mathrm{E}-\mathrm{OE}$ & 3.99E-05 & $(2.2 \mathrm{E}-04)$ \\
\hline _cut1 & $-1.301^{* * *}$ & $(0.084)$ \\
\hline _cut2 & $0.267^{* * *}$ & $(0.083)$ \\
\hline $\mathrm{N}$ & \multicolumn{2}{|c|}{991041} \\
\hline Log-likelihood & \multicolumn{2}{|c|}{-965191.237} \\
\hline Significance levels: & $10 \%$ & $*: 1 \%$ \\
\hline
\end{tabular}




\begin{tabular}{ccc}
\hline \hline Variable & Coefficient & (Std. err.) \\
\hline
\end{tabular}

Standard Errors are robust with respect to correlations within ageeducation cells. Abbreviations, see appendix.

Table 16: Decile transitions

\begin{tabular}{lcc}
\hline \hline \multicolumn{1}{c}{ Variable } & Coefficient & (Std. err.) \\
\hline 28-30 years & $-0.149^{* * *}$ & $(0.036)$ \\
31-33 years & $-0.215^{* * *}$ & $(0.039)$ \\
34-36 years & $-0.266^{* * *}$ & $(0.039)$ \\
37-39 years & $-0.308^{* * *}$ & $(0.039)$ \\
40-42 years & $-0.388^{* * *}$ & $(0.041)$ \\
43-45 years & $-0.421^{* * *}$ & $(0.044)$ \\
46-48 years & $-0.453^{* * *}$ & $(0.049)$ \\
49-51 years & $-0.479^{* * *}$ & $(0.057)$ \\
52-54 years & $-0.524^{* * *}$ & $(0.054)$ \\
Time & 0.004 & $(0.003)$ \\
Medium-skilled & $0.276^{* * *}$ & $(0.048)$ \\
High-skilled & $0.254^{* * *}$ & $(0.038)$ \\
Job change dummy & $0.339^{* * *}$ & $(0.010)$ \\
Job change x 28-30 years & 0 & $(0.027)$ \\
Job change x 31-33 years & $-0.033^{* *}$ & $(0.016)$ \\
Job change x 34-36 years & $-0.051^{* * *}$ & $(0.011)$ \\
Job change x 37-39 years & $-0.082^{* * *}$ & $(0.014)$ \\
Job change x 40-42 years & $-0.134^{* * *}$ & $(0.012)$ \\
Job change x 43-45 years & $-0.101^{* * *}$ & $(0.019)$ \\
Job change x 46-48 years & $-0.125^{* * *}$ & $(0.015)$ \\
Job change x 49-51 years & $-0.114^{* * *}$ & $(0.015)$ \\
Job change x 52-54 years & $-0.128^{* * *}$ & $(0.020)$ \\
Interquantile range/1000 & -0.419 & $(1.127)$ \\
E-E/10000 & $-0.743^{* * *}$ & $(0.154)$ \\
_cut1 & 6.856 & $(5.552)$ \\
_cut2 & 8.420 & $(5.554)$ \\
\hline
\end{tabular}

\begin{tabular}{|c|c|}
\hline $\mathrm{N}$ & 991041 \\
\hline Log-likelihood & -966348.106 \\
\hline
\end{tabular}

Standard Errors are robust with respect to correlations within ageeducation cells. Abbreviations, see appendix. 
Table 17: Decile transitions for changers

\begin{tabular}{|c|c|c|c|}
\hline Variable & $\begin{array}{l}\text { Education } \\
\text { category } 1\end{array}$ & $\begin{array}{l}\text { Education } \\
\text { category } 2\end{array}$ & $\begin{array}{l}\text { Education } \\
\text { category } 3\end{array}$ \\
\hline \multirow[t]{2}{*}{$28-30$ years } & -0.002 & $-0.180^{* * *}$ & $0.601^{* * *}$ \\
\hline & $(0.074)$ & $(0.019)$ & $(0.167)$ \\
\hline \multirow[t]{2}{*}{ 31-33 years } & -0.028 & $-0.277^{* * *}$ & $0.292^{* *}$ \\
\hline & $(0.083)$ & $(0.025)$ & $(0.143)$ \\
\hline \multirow[t]{2}{*}{$34-36$ years } & -0.075 & $-0.339^{* * *}$ & -0.082 \\
\hline & $(0.086)$ & $(0.027)$ & $(0.111)$ \\
\hline \multirow[t]{2}{*}{ 37-39 years } & -0.066 & $-0.418^{* * *}$ & $-0.397^{* * *}$ \\
\hline & $(0.088)$ & $(0.031)$ & $(0.082)$ \\
\hline \multirow[t]{2}{*}{ 40-42 years } & $-0.208^{*}$ & $-0.531^{* * *}$ & $-0.678^{* * *}$ \\
\hline & $(0.107)$ & $(0.034)$ & $(0.095)$ \\
\hline \multirow[t]{2}{*}{$43-45$ years } & -0.129 & $-0.550^{* * *}$ & $-0.937^{* * *}$ \\
\hline & $(0.118)$ & $(0.035)$ & $(0.110)$ \\
\hline \multirow[t]{2}{*}{$46-48$ years } & -0.162 & $-0.615^{* * *}$ & $-1.066^{* * *}$ \\
\hline & $(0.129)$ & $(0.036)$ & $(0.123)$ \\
\hline \multirow{2}{*}{ 49-51 years } & -0.219 & $-0.635^{* * *}$ & $-1.282^{* * *}$ \\
\hline & $(0.135)$ & $(0.038)$ & $(0.155)$ \\
\hline \multirow[t]{2}{*}{$52-54$ years } & -0.175 & $-0.662^{* * *}$ & $-1.389^{* * *}$ \\
\hline & $(0.131)$ & $(0.039)$ & $(0.169)$ \\
\hline \multirow[t]{2}{*}{ Interquantile range } & 0.005 & $0.002^{* * *}$ & $-0.013^{* * *}$ \\
\hline & $(0.007)$ & $(0.000)$ & $(0.003)$ \\
\hline \multirow[t]{2}{*}{$\mathrm{E}-\mathrm{OE}$} & 0.002 & 0.000 & -0.006 \\
\hline & $(0.003)$ & $(0.000)$ & $(0.005)$ \\
\hline \multirow[t]{2}{*}{ E-E } & 0.000 & $0.000^{* *}$ & 0.000 \\
\hline & $(0.000)$ & $(0.000)$ & $(0.001)$ \\
\hline \multirow[t]{2}{*}{ _cut1 } & $-0.411^{* *}$ & $-1.101^{* * *}$ & $-2.116^{* * *}$ \\
\hline & $(0.195)$ & $(0.107)$ & $(0.189)$ \\
\hline \multirow[t]{2}{*}{ _cut2 } & $0.432^{* *}$ & $-0.171^{* *}$ & $-0.803^{* * *}$ \\
\hline & $(0.205)$ & $(0.083)$ & $(0.081)$ \\
\hline $\mathrm{N}$ & 6587 & 59500 & 9821 \\
\hline Log-likelihood & -6945.001 & -61892.24 & -9074.522 \\
\hline
\end{tabular}


Table 18: Decile transitions for stayers

\begin{tabular}{|c|c|c|c|}
\hline Variable & $\begin{array}{l}\text { Education } \\
\text { category } 1\end{array}$ & $\begin{array}{l}\text { Education } \\
\text { category } 2\end{array}$ & $\begin{array}{l}\text { Education } \\
\text { category } 3\end{array}$ \\
\hline 28-30 years & $\begin{array}{c}-0.134^{* * *} \\
(0.011)\end{array}$ & $\begin{array}{c}-0.215^{* * *} \\
(0.027)\end{array}$ & $\begin{array}{c}0.987^{* * *} \\
(0.341)\end{array}$ \\
\hline 31-33 years & $\begin{array}{c}-0.169^{* * *} \\
(0.012)\end{array}$ & $\begin{array}{c}-0.316^{* * *} \\
(0.035)\end{array}$ & $\begin{array}{l}0.632^{*} \\
(0.335)\end{array}$ \\
\hline $34-36$ years & $\begin{array}{c}-0.191^{* * *} \\
(0.011)\end{array}$ & $\begin{array}{c}-0.392^{* * *} \\
(0.040)\end{array}$ & $\begin{array}{c}0.141 \\
(0.257)\end{array}$ \\
\hline 37-39 years & $\begin{array}{c}-0.180^{* * *} \\
(0.012)\end{array}$ & $\begin{array}{c}-0.452^{* * *} \\
(0.045)\end{array}$ & $\begin{array}{l}-0.257 \\
(0.182)\end{array}$ \\
\hline 40-42 years & $\begin{array}{c}-0.216^{* * *} \\
(0.016)\end{array}$ & $\begin{array}{c}-0.552^{* * *} \\
(0.050)\end{array}$ & $\begin{array}{c}-0.637^{* * *} \\
(0.150)\end{array}$ \\
\hline $43-45$ years & $\begin{array}{c}-0.272^{* * *} \\
(0.017)\end{array}$ & $\begin{array}{c}-0.616^{* * *} \\
(0.052)\end{array}$ & $\begin{array}{c}-0.971^{* * *} \\
(0.142)\end{array}$ \\
\hline $46-48$ years & $\begin{array}{c}-0.275^{* * *} \\
(0.020)\end{array}$ & $\begin{array}{c}-0.679^{* * *} \\
(0.055)\end{array}$ & $\begin{array}{c}-1.184^{* * *} \\
(0.175)\end{array}$ \\
\hline 49-51 years & $\begin{array}{c}-0.285^{* * *} \\
(0.022)\end{array}$ & $\begin{array}{c}-0.736^{* * *} \\
(0.059)\end{array}$ & $\begin{array}{c}-1.470^{* * *} \\
(0.228)\end{array}$ \\
\hline $52-54$ years & $\begin{array}{c}-0.289^{* * *} \\
(0.024)\end{array}$ & $\begin{array}{c}-0.745^{* * *} \\
(0.060)\end{array}$ & $\begin{array}{c}-1.583^{* * *} \\
(0.270)\end{array}$ \\
\hline Interquantile range & $\begin{array}{c}0.014^{* * *} \\
(0.005)\end{array}$ & $\begin{array}{c}0.004^{* * *} \\
(0.001)\end{array}$ & $\begin{array}{c}-0.021^{* * *} \\
(0.005)\end{array}$ \\
\hline $\mathrm{E}-\mathrm{OE}$ & $\begin{array}{c}0.000 \\
(0.001)\end{array}$ & $\begin{array}{c}0.000 \\
(0.000)\end{array}$ & $\begin{array}{c}-0.011^{*} \\
(0.006)\end{array}$ \\
\hline E-E & $\begin{array}{c}0.000^{* * *} \\
(0.000)\end{array}$ & $\begin{array}{c}0.000^{* * *} \\
(0.000)\end{array}$ & $\begin{array}{c}0.001 \\
(0.001)\end{array}$ \\
\hline _cut1 & $\begin{array}{c}-0.699^{* * *} \\
(0.097)\end{array}$ & $\begin{array}{c}-1.587^{* * *} \\
(0.090)\end{array}$ & $\begin{array}{c}-3.070^{* * *} \\
(0.315)\end{array}$ \\
\hline _cut2 & $\begin{array}{c}0.682^{* * *} \\
(0.103)\end{array}$ & $\begin{array}{c}0.064 \\
(0.070) \\
\end{array}$ & $\begin{array}{c}-1.058^{* * *} \\
(0.228)\end{array}$ \\
\hline$N$ & 129368 & 698954 & 86811 \\
\hline Log-likelihood & -133156.035 & -666708.572 & -70199.603 \\
\hline
\end{tabular}


Table 19: Decile transitions for unemployed

\begin{tabular}{|c|c|c|c|}
\hline$\overline{\text { Variable }}$ & $\begin{array}{l}\text { Education } \\
\text { category } 1\end{array}$ & $\begin{array}{l}\text { Education } \\
\text { category } 2\end{array}$ & $\begin{array}{l}\text { Education } \\
\text { category } 3\end{array}$ \\
\hline $28-30$ years & $\begin{array}{l}-0.007 \\
(0.028)\end{array}$ & $\begin{array}{c}-0.195^{* * *} \\
(0.018)\end{array}$ & $\begin{array}{c}0.028 \\
(0.026)\end{array}$ \\
\hline 31-33 years & $\begin{array}{c}-0.165^{* * *} \\
(0.045)\end{array}$ & $\begin{array}{c}-0.302^{* * *} \\
(0.030)\end{array}$ & $\begin{array}{c}0.284^{* * *} \\
(0.056)\end{array}$ \\
\hline 34-36 years & $\begin{array}{l}-0.088 \\
(0.061)\end{array}$ & $\begin{array}{c}-0.430^{* * *} \\
(0.038)\end{array}$ & $\begin{array}{c}0.021 \\
(0.069)\end{array}$ \\
\hline 37-39 years & $\begin{array}{c}-0.282^{* * *} \\
(0.045)\end{array}$ & $\begin{array}{c}-0.441^{* * *} \\
(0.046)\end{array}$ & $\begin{array}{c}-0.014 \\
(0.064)\end{array}$ \\
\hline 40-42 years & $\begin{array}{c}-0.235^{* * *} \\
(0.043)\end{array}$ & $\begin{array}{c}-0.598^{* * *} \\
(0.049)\end{array}$ & $\begin{array}{c}0.047 \\
(0.039)\end{array}$ \\
\hline $43-45$ years & $\begin{array}{c}-0.334^{* * *} \\
(0.052)\end{array}$ & $\begin{array}{c}-0.591^{* * *} \\
(0.051)\end{array}$ & $\begin{array}{c}0.007 \\
(0.022)\end{array}$ \\
\hline $46-48$ years & $\begin{array}{c}-0.394^{* * *} \\
(0.038)\end{array}$ & $\begin{array}{c}-0.655^{* * *} \\
(0.055)\end{array}$ & $\begin{array}{c}-0.051^{*} \\
(0.029)\end{array}$ \\
\hline 49-51 years & $\begin{array}{c}-0.373^{* * *} \\
(0.035)\end{array}$ & $\begin{array}{c}-0.778^{* * *} \\
(0.057)\end{array}$ & $\begin{array}{l}-0.006 \\
(0.025)\end{array}$ \\
\hline $52-54$ years & $\begin{array}{c}-0.487^{* * *} \\
(0.043)\end{array}$ & $\begin{array}{c}-0.716^{* * *} \\
(0.058)\end{array}$ & $\begin{array}{c}-0.048^{* *} \\
(0.023)\end{array}$ \\
\hline Interquantile range & $\begin{array}{c}0.008 \\
(0.016)\end{array}$ & $\begin{array}{l}0.001^{* *} \\
(0.001)\end{array}$ & $\begin{array}{c}0.000 \\
(0.001)\end{array}$ \\
\hline U-E & $\begin{array}{c}0.002 \\
(0.005)\end{array}$ & $\begin{array}{c}0.000 \\
(0.000)\end{array}$ & $\begin{array}{c}0.017 \\
(0.010)\end{array}$ \\
\hline _cut1 & $\begin{array}{c}-0.542^{*} \\
(0.284)\end{array}$ & $\begin{array}{c}-0.903^{* * *} \\
(0.107)\end{array}$ & $\begin{array}{c}-0.508^{* * *} \\
(0.044)\end{array}$ \\
\hline _cut2 & $\begin{array}{c}0.381 \\
(0.309)\end{array}$ & $\begin{array}{c}0.053 \\
(0.044) \\
\end{array}$ & $\begin{array}{c}0.568^{* * *} \\
(0.042) \\
\end{array}$ \\
\hline $\mathrm{N}$ & 1704 & 10989 & 1039 \\
\hline Log-likelihood & -1827.02 & -11617.305 & -1108.274 \\
\hline
\end{tabular}

